\title{
Cytogenetics and cytotaxonomy of some Brazilian species of Cymbidioid orchids
}

\author{
Leonardo Pessoa Félix ${ }^{1}$ and Marcelo Guerra ${ }^{2}$ \\ ${ }^{\prime}$ Departamento de Fitotecnia, Centro de Ciências Agrárias, Universidade Federal da Paraiba, Campus III, 58397-000 Areia, PB, Brasil. \\ ${ }^{2}$ Departamento de Botânica, Centro de Ciências Biológicas, Universidade Federal de Pernambuco, Av. Prof. Nelson Chaves, \\ S/N, 50732-970 Recife, PE, Brasil. Send correspondence to M.G. E-mailmguerra@npd.ufpe.br
}

\section{Abstract}

The Cymbidioid phylad presents the widest chromosome number variation among orchids, with records varying from $2 \mathrm{n}=10$ in Psygmorchis pusilla to $2 \mathrm{n}=168$ in two species of Oncidium. In the present work, a total of 44 species were studied belonging to 20 Cymbidioid genera, as a contribution to clarifying the karyological evolution of the group. All the plants investigated were collected in Brazil, mainly in the northeast region. The chromosome variation found was similar to that previously registered in the literature. Chromosome numbers observed were: $2 n=54$ (subtribe Eulophiinae), $2 \mathrm{n}=44,46,92$ (subtribe Cyrtopodiinae), $2 \mathrm{n}=54$, ca. 108 (subtribe Catasetinae), $2 \mathrm{n}=52$, ca. 96 (subtribe Zygopetalinae), $2 \mathrm{n}=40,80$ (subtribe Lycastinae), $2 \mathrm{n}=40,42$ (subtribe Maxillariinae), $2 \mathrm{n}=40$ (subtribe Stanhopeinae), $2 \mathrm{n}=56$ (subtribe Ornithocephalinae), and $2 \mathrm{n}=12,20,30,36,42,44$, 56,112 , ca. 168 (subtribe Oncidiinae). Interphase nuclei varied widely from simple chromocenter to complex chromocenter types, with no apparent cytotaxonomic value. In the genera Catasetum and Oncidium, the terrestrial and lithophytic species presented higher ploidy levels than the epiphytic species, suggesting a higher adaptability of the polyploids to those habitats. The primary base number $\mathrm{x}=7$ seems to be associated to the haploid chromosome numbers of most $C y$ mbidioid groups, although $\mathrm{n}=7$ was observed only in two extant genera of Oncidiinae. For each tribe, subtribe and genus the probable base numbers were discussed along with the possible relationships to the primary base number $x_{1}=7$ admitted for the whole phylad.

\section{INTRODUCTION}

The Cymbidioid phylad (sensu Dressler, 1993) consists mainly of pantropical epiphytic species, with approximately 275 genera and 4300 species, including 86 genera and 654 species throughout Brazil (Pabst and Dungs, 1977). The phylad is formed basically by the ancient subfamily Vandoideae (sensu Dressler, 1981), excluding the tribes Polystachieae and Vandeae, and is characterized by having two polinia whose texture varies from firm to hard (Dressler, 1993). It is a morphologically variable group, including ornamental species, mainly in the subtribes Cyrtopodiinae (Cymbidium) and Oncidiinae (Odontoglossum, Miltonia and Oncidium), which have been more widely studied cytologically (see, e.g., Sinotô, 1962; Charanasri et al., 1973).

Cymbidioid phylad has the highest variation in chro- mosome number of all orchids: $2 \mathrm{n}=10$ in Psygmorchis pusilla (Dodson, 1957a,b) to $2 \mathrm{n}=168$ in a horticultural variety of Oncidium varicosum (Sinotô, 1962). There are previous reports for approximately 495 species distributed throughout 60 genera, of which 47 species belonging to 39 genera are from Brazil, representing $9.93 \%$ of all species analyzed. Oncidium, Catasetum, Stanhopea, Brassia, Miltonia, and Zygopetalum are the best studied of these genera (Blumenschein, 1960a). Chromosome number variation in Cymbidioid phylad and orchids as a whole is intriguing because most of the genera have high ploidy levels and variable base numbers (Goldblatt, 1980; Ehrendorfer, 1980). The base number of the family is still uncertain, difficulting to estimate species ploidy level and to understand the karyological evolution of the family. Raven (1975) reviewed the angiosperm's base number and considered it premature to suggest a base number for Orchidaceae.

In the present study, chromosome number and interphase nuclear types were investigated relative to 44 species of 20 genera of Cymbidioid orchids occurring in Brazil. Besides, the variability in chromosome number within the phylad was reviewed, along with its compatibility with the taxonomic treatment proposed by Dressler (1993), and the most probable base number for each genus, subtribe and tribe of the group.

\section{MATERIAL AND METHODS}

All species analyzed in the present work were collected on excursions throughout Brazil, especially in northeast region. The material was cultivated in the greenhouse of the Universidade Federal Rural de Pernambuco and in the experimental garden of the Department of Botany at the Universidade Federal de Pernambuco. Vouchers were deposited in EAN, JPB, PEUFR, HST and UFP Herbaria (acronyms in agreement with Mori et al., 1989). For each species, whenever possible, a minimum of three individuals and more than one population were analyzed (Table I). The identifications were based on Cogniaux (1906), Hoehne (1942, 1953) and Pabst and Dungs $(1975,1977)$ and, in some cases, submitted and identified by specialists.

Mitotic analyses were undertaken mainly on root tips or ovary walls pretreated with $0.002 \mathrm{M} 8$-hydroxyquinoline at $4^{\circ} \mathrm{C}$ for $24 \mathrm{~h}$. Root tips and young flower buds (for 
mitotic or meiotic analysis) were fixed in Carnoy 3:1 (ethanol/acetic acid) for a period varying from 3 to $24 \mathrm{~h}$ and later stored at $-20^{\circ} \mathrm{C}$ in the same solution. For slide preparation, the material was hydrolyzed in $5 \mathrm{~N} \mathrm{HCl}$ for 20-30 min at room temperature and stained with Giemsa 2\% (Guerra, 1983) or hematoxylin at 1\% (Guerra, 1999). Photomicrographs were taken with Kodak Imagelink or Agfa Copex Pan films, using a Leica DMRB photomicroscope adjusted to 25 ASA.

\section{RESULTS AND DISCUSSION}

\section{Karyological variation}

A total of 44 species belonging to 20 genera and two of the four tribes from Cymbidioid phylad were analyzed (Table I). Chromosome numbers varied from $2 \mathrm{n}=12$ in Psygmorchis pusilla to $2 \mathrm{n}=$ ca. 168 in Oncidium aff. flexuosum. No interpopulational numeric variation was observed in species with more than one population analyzed (Bifrenaria magnicalcarata, Catasetum discolor, Cyrtopodium intermedium, C. paranaense, Notylia lyrata, On- cidium barbatum, O. cebolleta, Psygmorchis pusilla, Rodriguezia bahiensis and Trichocentrum cornucopiae). In Oeceoclades maculata, samples of four populations produced clumped cells with $2 \mathrm{n}=\mathrm{ca}$. 52 , but in other three populations, in which the best metaphase was obtained, $2 \mathrm{n}$ $=54$ was always observed (Figure 1a), suggesting that they have the same number.

Figures 1 to 5 illustrate the karyotype of all species analyzed. Chromosome morphology, whenever observed, was very variable, with metacentric, submetacentric and acrocentric chromosomes in almost all species. Satellites were observed in a few species, and up to two satellites were found in Catasetum barbatum, Coryanthes speciosa, Trichocentrum cornucopiae, Oncidium pumillum and Notylia lyrata.

The interphase nuclei varied from the simple to complex chromocenter types, according to the classification of Tanaka (1971). In Dichaea panamensis, Catasetum barbatum, C. discolor, C. luridum, Dipteranthus duchii, Dipteranthus sp., Cyrtopodium blanchetii, Gongora quinquenervis, Oeceoclades maculata, Trigonidium acuminatum and T. obtusum, along with all the species of

Table I - List of species analyzed with respective chromosome numbers ( $\mathrm{n}$ and/or $2 \mathrm{n}$ ), provenances, habitats, numbers of collector and herbarium where each material is deposited.

\begin{tabular}{|c|c|c|c|c|c|c|}
\hline Species & $\mathrm{n}$ & $2 n$ & Provenance & Habitat & Collector (No.) & Herbarium \\
\hline \multicolumn{7}{|l|}{ TRIBE CYMBIDIEAE } \\
\hline \multicolumn{7}{|l|}{ Subtribe Eulophiinae } \\
\hline \multirow{7}{*}{ Oeceoclades maculata (Lindl.) Lindl. } & & ca. 52 & Sete Cidades, PI & Terrestrial & L.P. Felix et al., S/N & HST \\
\hline & & ca. 52 & Maranguape, CE & Terrestrial & L.P. Felix, S/N & HST \\
\hline & & ca. 52 & Bezerros, PE & Terrestrial & L.P. Felix, 8916 & HST \\
\hline & & ca. 52 & Rio de Contas, BA & Terrestrial & L.P. Felix, 8677 & PEUFR \\
\hline & & 54 & Goiana, PE & Terrestrial & L.P. Felix, S/N & PEUFR \\
\hline & & 54 & Cabo, PE & Terrestrial & L.P. Felix, 8956 & PEUFR \\
\hline & & 54 & Recife, PE & Terrestrial & L.P. Felix, 9378 & PEUFR \\
\hline \multicolumn{7}{|l|}{ Subtribe Cyrtopodiinae } \\
\hline Cyrtopodium blanchetii Rchb. f. & & 92 & Santa Rita, PB & Terrestrial & L.P. Felix, S/N & JPB \\
\hline C. gigas (Vell.) Hoehne & & 46 & Juazeiro, BA & Epiphytic & L.P. Felix, 8541 & EAN \\
\hline C. inaldianum L.C. Menezes & & 46 & Conde, PB & Terrestrial & L.P. Felix, S/N & EAN \\
\hline \multirow[t]{2}{*}{ C. intermedium Brade } & & 46 & Bezerros, PE & Terrestrial & L.P. Felix, 8990 & PEUFR \\
\hline & 23 & & Camocim do São Félix, PE & Terrestrial & L.P. Felix, 9370 & PEUFR \\
\hline \multirow[t]{2}{*}{ C. paranaense Schltr. } & & 46 & Bezerros, PE & Terrestrial/Lithophytic & L.P. Felix, 7692 & PEUFR \\
\hline & & 46 & São Lourenço da Mata, PE & Terrestrial & J. Alves, S/N & UFP \\
\hline Cyrtopodium eugenii Rchb. f. & 22 & & Ibicoara, BA & Terrestrial & L.P. Felix, 8797 & HST \\
\hline \multicolumn{7}{|l|}{ Subtribe Catasetinae } \\
\hline Catasetum barbatum Lindl. & & 54 & União, PI & Epiphytic & L.P. Felix et al., 9043 & HST \\
\hline C. luridum (Link) Lindl. & & 54 & José de Freitas, PI & Epiphytic & L.P. Felix, 9042 & HST \\
\hline \multirow[t]{2}{*}{ C. discolor Lindl. } & & ca. 108 & Camocim do São Félix, PE & Terrestrial/Lithophytic & L.P. Felix, 9047 & EAN \\
\hline & & ca. 108 & Bonito, PE & Terrestrial/Lithophytic & L.P. Felix, 8379 & HST \\
\hline C. macrocarpum Rich. & & 54 & Cabo, PE & Epiphytic & L.P. Felix, 9393 & HST \\
\hline C. purum Nees e Sinnings & & 54 & Carmópolis, SE & Epiphytic & L.P. Felix, 8818 & PEUFR \\
\hline \multicolumn{7}{|l|}{ TRIBE MAXILLARIEAE } \\
\hline \multicolumn{7}{|l|}{ Subtribe Zygopetalinae } \\
\hline Dichaea panamensis Lindl. & & 52 & Cabo, PE & Epiphytic & L.P. Felix, 8380 & HST \\
\hline Koelensteinia tricolor (Lindl.) Rchb. f. & & ca. 96 & Ouro Preto, MG & Terrestrial & L.P. Felix, 9331 & PEUFR \\
\hline \multicolumn{7}{|l|}{ Subtribe Lycastinae } \\
\hline \multirow[t]{2}{*}{ Bifrenaria magnicalcarata (Hoehne) Pabst } & & 80 & Morro do Chapéu, BA & Lithophytic & L.P. Felix, 8627 & PEUFR \\
\hline & & 80 & Rio de Contas, BA & Lithophytic & L.P. Felix, 8837 & PEUFR \\
\hline Xylobium foveatum (Lindl.) Nichols & & 40 & Santa Teresinha, BA & Epiphytic & L.P. Felix, 8856 & HST \\
\hline
\end{tabular}




\begin{tabular}{|c|c|c|c|c|c|c|}
\hline Species & $\mathrm{n}$ & $2 \mathrm{n}$ & Provenance & Habitat & Collector (No.) & Herbarium \\
\hline \multicolumn{7}{|l|}{ Subtribe Maxillariinae } \\
\hline Maxillaria discolor (Lodd. ex Lindl.) Rchb. f. & & 42 & Belo Jardim, PE & Epiphytic & L.P. Felix, 9052 & EAN \\
\hline M. rufescens Lindl. & & 40 & Domingos Martins, ES & Epiphytic & L.P. Felix, 9361 & PEUFR \\
\hline Trigonidium acuminatum Batem. ex Lindl. & & 40 & Esperança, PB & Lithophytic & L.P. Felix, 9377 & \\
\hline T. obtusum Lindl. & & 40 & Belo Jardim, PE & Epiphytic & L.P. Felix, 9053 & EAN \\
\hline \multicolumn{7}{|l|}{ Subtribe Stanhopeinae } \\
\hline Coryanthes speciosa Hook. & & 40 & Maceió, Al & Epiphytic & L.P. Felix, 9389 & PEUFR \\
\hline Gongora quinquenervis Ruiz \& Pavon & & 40 & Belo Jardim, PE & Epiphytic & L.P. Felix, 8298 & HST \\
\hline \multicolumn{7}{|l|}{ Subtribe Ornithocephalinae } \\
\hline Dipteranthus duchii Pabst & & ca. 56 & Bonito, PE & Epiphytic & L.P. Felix, 8948 & EAN \\
\hline Dipeteranthus sp. & & 56 & Areia, PB & Epiphytic & L.P. Felix, 9055 & EAN \\
\hline \multicolumn{7}{|l|}{ Subtribe Oncidiinae } \\
\hline Brassia lawrenciana Lindl. & & 60 & Recife, PE & Cultivated & L.P. Felix, 9395 & PEUFR \\
\hline \multirow[t]{2}{*}{ Lockartia goyazensis Rchb. f. } & & 56 & Piracanjuba, GO & Epiphytic & L.P. Felix, 9376 & PEUFR \\
\hline & & 56 & Foz do Iguaçu, PR & Cultivated & M. Guerra, S/N & PEUFR \\
\hline Miltonia flavescens Lindl. & & 60 & Rio de Janeiro, RJ & Epiphytic & L.P. Felix, 9394 & PEUFR \\
\hline \multirow[t]{2}{*}{ Notylia lyrata S.P. Moore } & & ca. 44 & Areia, PB & Epiphytic & L.P. Felix, 9045 & EAN \\
\hline & & 44 & Morro do Chapéu, BA & Epiphytic & L.P. Felix, 8679 & PEUFR \\
\hline \multirow[t]{3}{*}{ Oncidium barbatum Lindl. } & & 56 & São Lourenço da Mata, PE & Epiphytic & L.P. Felix, 9046 & HST \\
\hline & & 56 & Morro do Chapéu, BA & Epiphytic & L.P. Felix, S/N & PEUFR \\
\hline & & 56 & Garanhuns, PE & Epiphytic & L.P. Felix, 8905 & PEUFR \\
\hline O. baueri Lindl. & & 56 & Recife, PE & Epiphytic & K. Santos, S/N & PEUFR \\
\hline O. blanchetii Rchb. f. & & ca. 112 & Morro do Chapéu, BA & Terrestrial & L.P. Felix, 8594 & HST \\
\hline \multirow[t]{2}{*}{ O. cebolleta $\mathrm{Sw}$. } & & 36 & Areia, PB & Epiphytic & L.P. Felix, S/N & EAN \\
\hline & & 36 & Gravatá, PE & Epiphytic & L.P. Felix, 8937 & EAN \\
\hline O. aff. Crispum Lodd. & & 56 & Domingos Martins, RS & Epiphytic & L.P. Felix, 9350 & PEUFR \\
\hline O. flexuosum Sims. & 28 & & Rio Grande, RS & Epiphytic & L.P. Felix, 8974 & HST \\
\hline$O$. aff. flexuosum Sims. & & ca. 168 & São Caetano, PE & Lithophytic & L.P. Felix, 8305 & HST \\
\hline O. gravesianum Rolfe & & 56 & Morro do Chapéu, BA & Epiphytic & L.P. Felix, 8629 & EAN \\
\hline O. loefgrenii Cogn. & 28 & 56 & Morro do Chapéu, BA & Epiphytic & L.P. Felix, 8929 & HST \\
\hline O. pumillum Lindl. & & 30 & Rio Grande, RS & Epiphytic & L.P. Felix, 8975 & HST \\
\hline O. varicosum Lindl. & 56 & 112 & Morro do Chapéu, BA & Epiphytic/Terrestrial & L.P. Felix, 8657 & PEUFR \\
\hline Oncidium paranaense Krzl. & & 56 & Piratini, RS & Epiphytic & L.P. Felix, 8967 & PEUFR \\
\hline \multirow[t]{2}{*}{ Psygmorchis pusilla (L.) Dodson \& Dressler } & 6 & 12 & Camocim do São Félix, PE & Epiphytic & L.P. Felix, 9048 & HST \\
\hline & 6 & 12 & Belém do Pará, PA & Epiphytic & L.P. Felix, 9413 & PEUFR \\
\hline \multirow[t]{2}{*}{ Rodriguezia bahiensis Rchb. f. } & & ca. 42 & Recife, PE & Epiphytic & L.P. Felix, 9049 & HST \\
\hline & & 42 & Maranguape, $\mathrm{CE}$ & Epiphytic & L.P. Felix, 8269 & EAN \\
\hline R. lanceolata Ruiz \& Pavon & & 42 & Acará, PA & Epiphytic & L.P. Felix, 9050 & EAN \\
\hline \multirow[t]{2}{*}{ Trichocentrum cornucopiae Lindl. \& Rchb. f. } & & 20 & Carmópolis, SE & Epiphytic & L.P. Felix, 9391 & HST \\
\hline & & 20 & Canavieiras, BA & Epiphytic & L.P. Felix, 8951 & HST \\
\hline
\end{tabular}

AL, Alagoas; BA, Bahia; CE, Ceará; GO, Goiás; MA, Maranhão; MG, Minas Gerais; PA, Pará; PB, Paraíba; PE, Pernambuco; PI, Piauí; RN, Rio Grande do Norte; RS, Rio Grande do Sul; SE, Sergipe.

Oncidiinae (except Brassia lawrenciana), interphase nuclei of simple chromocenter type were observed, with small heteropycnotic blocks and fibrous diffuse chromatin. Intermediate nuclei between simple and complex chromocenter types were observed in Cyrtopodium gigas, C. inaldianum, C. intermedium, C. paranaense, C. eugenii, Catasetum macrocarpum, C. purum and Brassia lawrenciana. These nuclei were characterized by the presence of several partially aggregate heteropycnotic blocks and irregular outline which were gradually transformed into diffuse chromatin. Interphase nuclei of the complex chromocenter type, with large, strongly stained heteropycnotic blocks, were found in Koelensteinia tricolor, Maxillaria discolor, M. rufescens, Coryanthes speciosa and Xylobium foveatum.

In some other families, analysis of the chromatin organization in interphase nuclei has contributed to an un- derstanding of the genomic diversification, independent of number and chromosome morphology (Morawetz, 1986; Röser, 1994). There is a general tendency toward the conservation of a single interphase nuclear type throughout a genus or a higher taxonomic category, as in Rutaceae, subfamily Aurantioideae (Guerra, 1987). In orchids, Tanaka (1971) described five different types of interphase nuclei based on observations in 115 species of 52 genera. However, the occurrence of more than one interphase nuclear type in a single genus has been described, as in Habenaria (Félix and Guerra, 1998) and Platanthera (Yokota, 1990). In Catasetum and Cyrtopodium, which present chromosome numbers and morphology relatively constant, two different types of interphase nuclei occur. Otherwise, the occurrence of simple chromocenter nuclei in nearly all Oncidiinae species seems to reflect the uniformity of this 

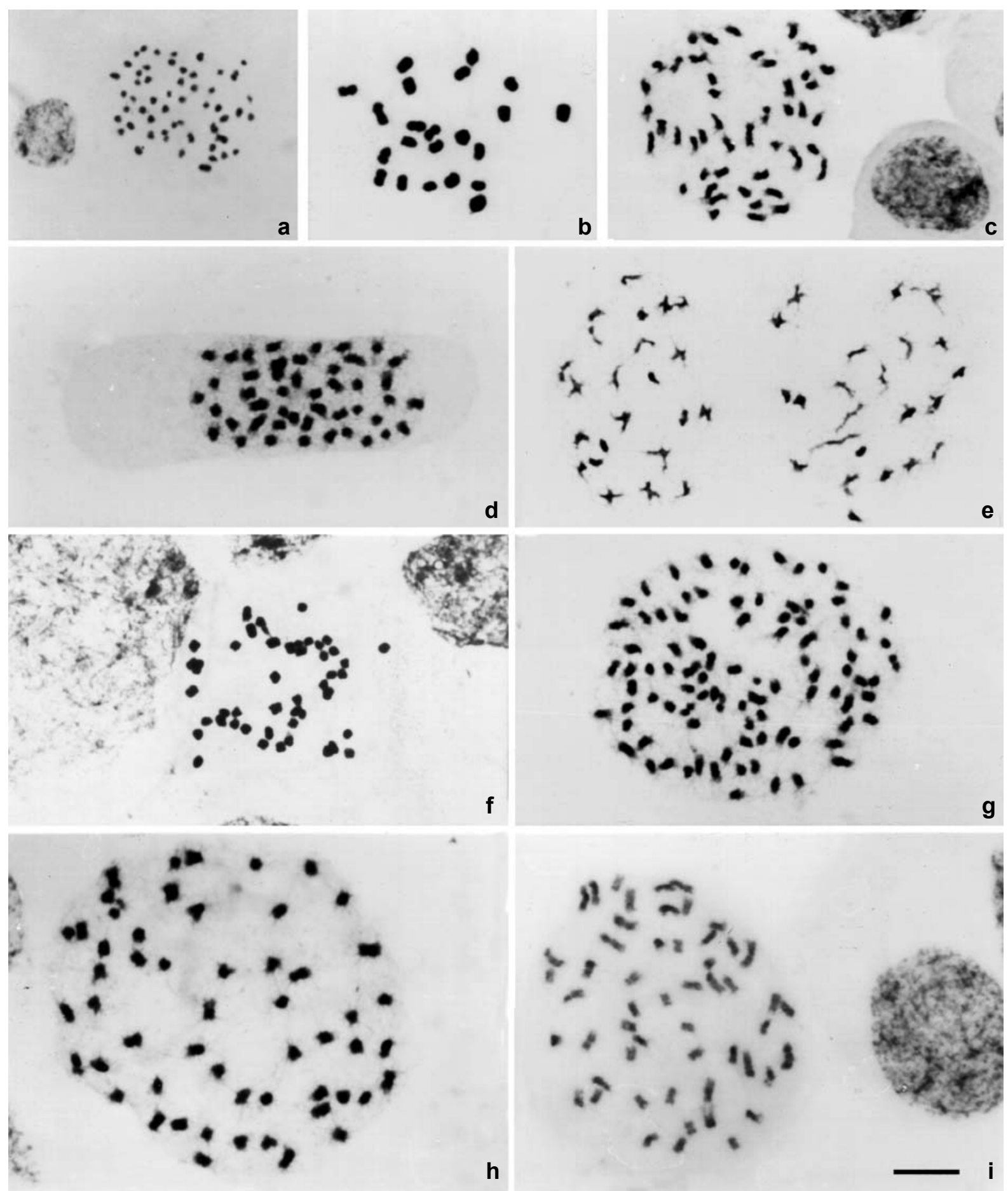

Figure 1 - Chromosome complements and interphase nuclei of orchid species of the subtribes Eulophiinae, Cyrtopodiineae and Catasetinae. (a) Oeceoclades maculata $(2 \mathrm{n}=$ ca. 52$)$ with two larger chromosome (bottom); (b) diakinesis of Cyrtopodium eugenii with 22 bivalents; (c) C. gigas $(2 \mathrm{n}=46)$; (d) C. inaldianum $(2 \mathrm{n}=46)$; (e) two cells in prophase II of C. intermedium $(\mathrm{n}=23) ;(\mathbf{f})$ C. paranaense $(2 \mathrm{n}=46) ;(\mathbf{g})$ C. blanchetii $(2 \mathrm{n}=92) ;(\mathbf{h})$ Catasetum barbatum $(\mathrm{n}=54)$, and $(\mathbf{i})$ C. luridum $(2 \mathrm{n}=54)$. Bar represents $10 \mu \mathrm{m}$.

group (Chase, 1986). Therefore, the meaning of this variation in orchids needs to be better understood.

The chromosome number variation of Cymbidioid seems to be much more elucidative. In order to attempt to understand the chromosome numeric variation of the phylad, a complete review of the recorded chromosome numbers was made, based on the review of Tanaka and Kamemoto (1984), followed by the chromosome number indexes published by Fedorov (1969), Moore (1973, 1974, 1977), Goldblatt $(1984,1985,1988)$ and Goldblatt and Johnson (1990, 1991, 1994, 1996). Furthermore, the chromosome numbers were checked in many original papers, although it 

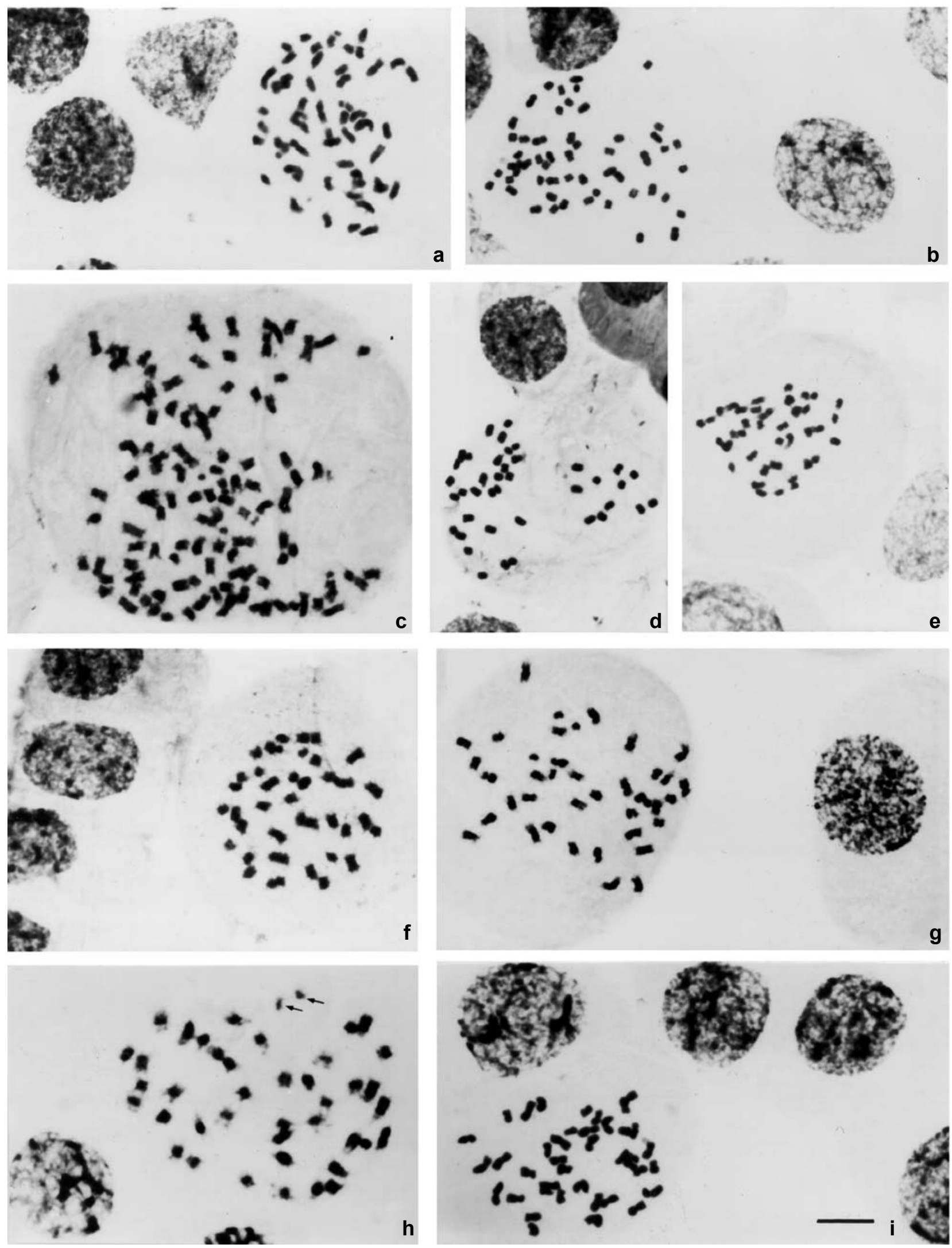

Figure 2 - Chromosome complements and interphase nuclei of orchid species of the subtribes Catasetinae, Maxillariinae, Stanhopeinae and Lycastinae. (a) Catasetum macrocarpum $(2 \mathrm{n}=54) ;(\mathbf{b})$ C. purum $(2 \mathrm{n}=54) ;(\mathbf{c})$ C. discolor $(2 \mathrm{n}=\mathrm{ca} .108) ;$ (d) Maxillaria rufescens $(2 \mathrm{n}=40) ;(\mathbf{e})$ Trigonidium acuminatum $(2 \mathrm{n}=40)$; (f) T. obtusum $(2 \mathrm{n}=40)$; (g) Gongora quinquenervis $(2 \mathrm{n}=40)$; (h) Coryanthes speciosa $(2 \mathrm{n}=40)$ (arrows indicate detached satellites), and (i) Xylobium foveatum $(2 \mathrm{n}=40)$. Bar represents $10 \mu \mathrm{m}$. 

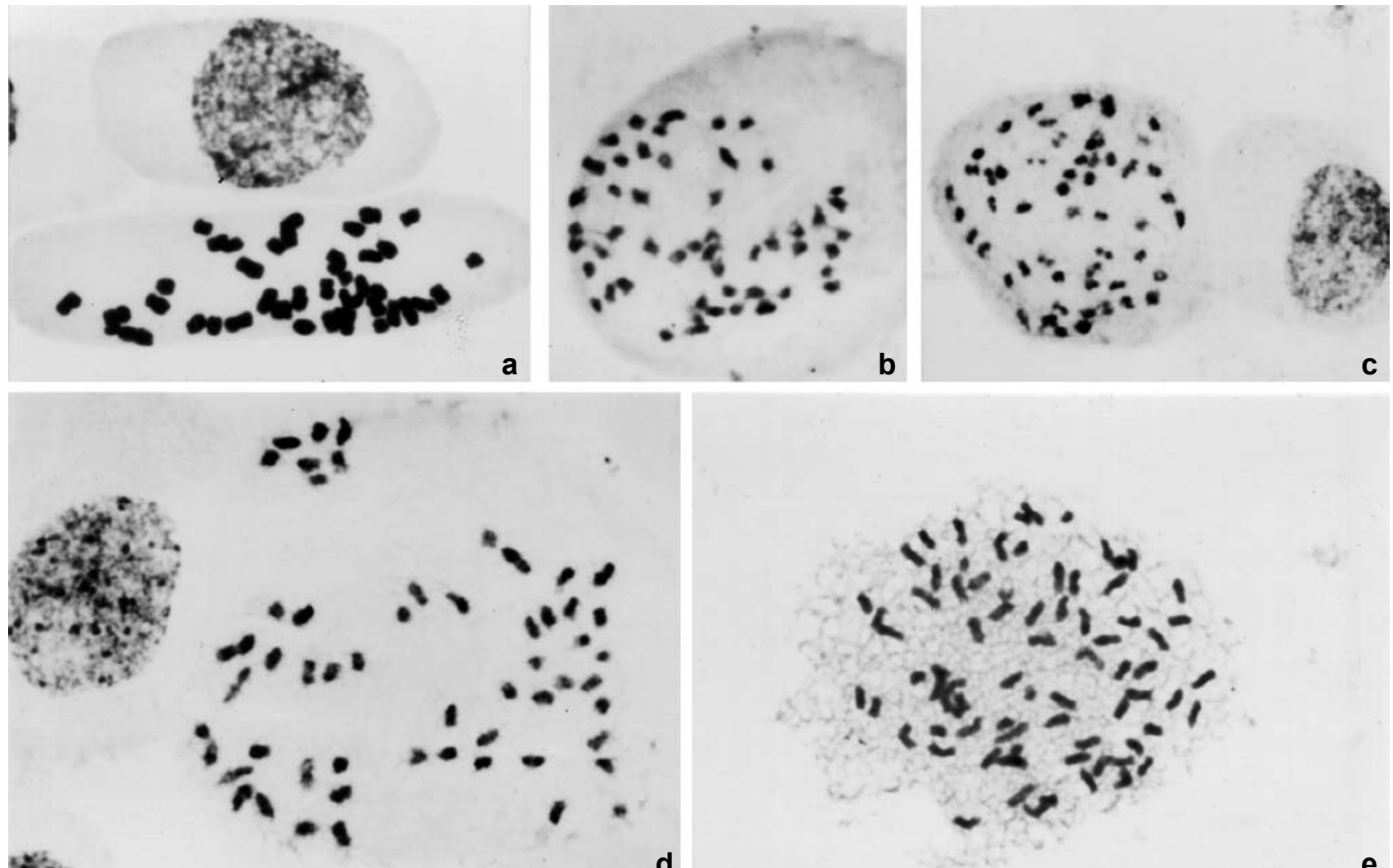

楼:

d
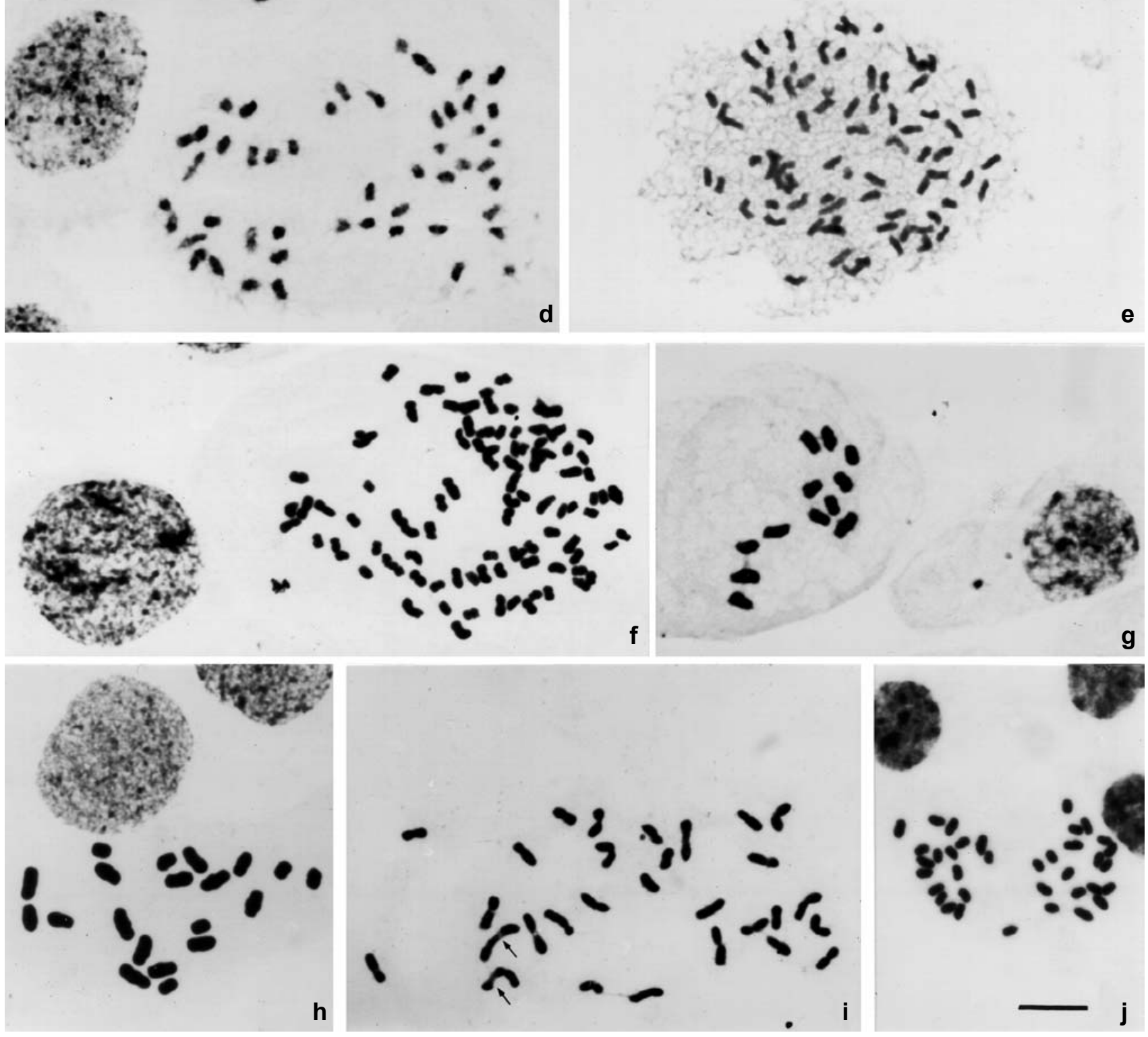

Figure 3 - Chromosome complements and interphase nuclei of orchid species of the subtribes Maxillariinae, Zygopetalinae, Lycastinae and Oncidiinae: (a) Maxillaria discolor $(2 \mathrm{n}=42)$; (b) Dichaea panamensis $(2 \mathrm{n}=52)$; (c) Dipteranthus duchii $(2 \mathrm{n}=$ ca. 56); (d) Dipteranthus $\mathrm{sp}$. $(2 \mathrm{n}=56)$; (e) Bifrenaria magnicalcarata $(2 \mathrm{n}=80) ;(\mathbf{f})$ Koelensteinia tricolor $(2 \mathrm{n}=$ ca. 96$) ;(\mathbf{g})$ Psygmorchis pusilla $(2 \mathrm{n}=12)$; (h) Trichocentrum cornucopiae ( $2 \mathrm{n}=20)$; (i) Oncidium pumillum $(2 \mathrm{n}=30)$ (arrows indicate secondary constriction), and $(\mathbf{j})$ O. cebolleta $(2 \mathrm{n}=36)$. Bar represents $10 \mu \mathrm{m}$. 

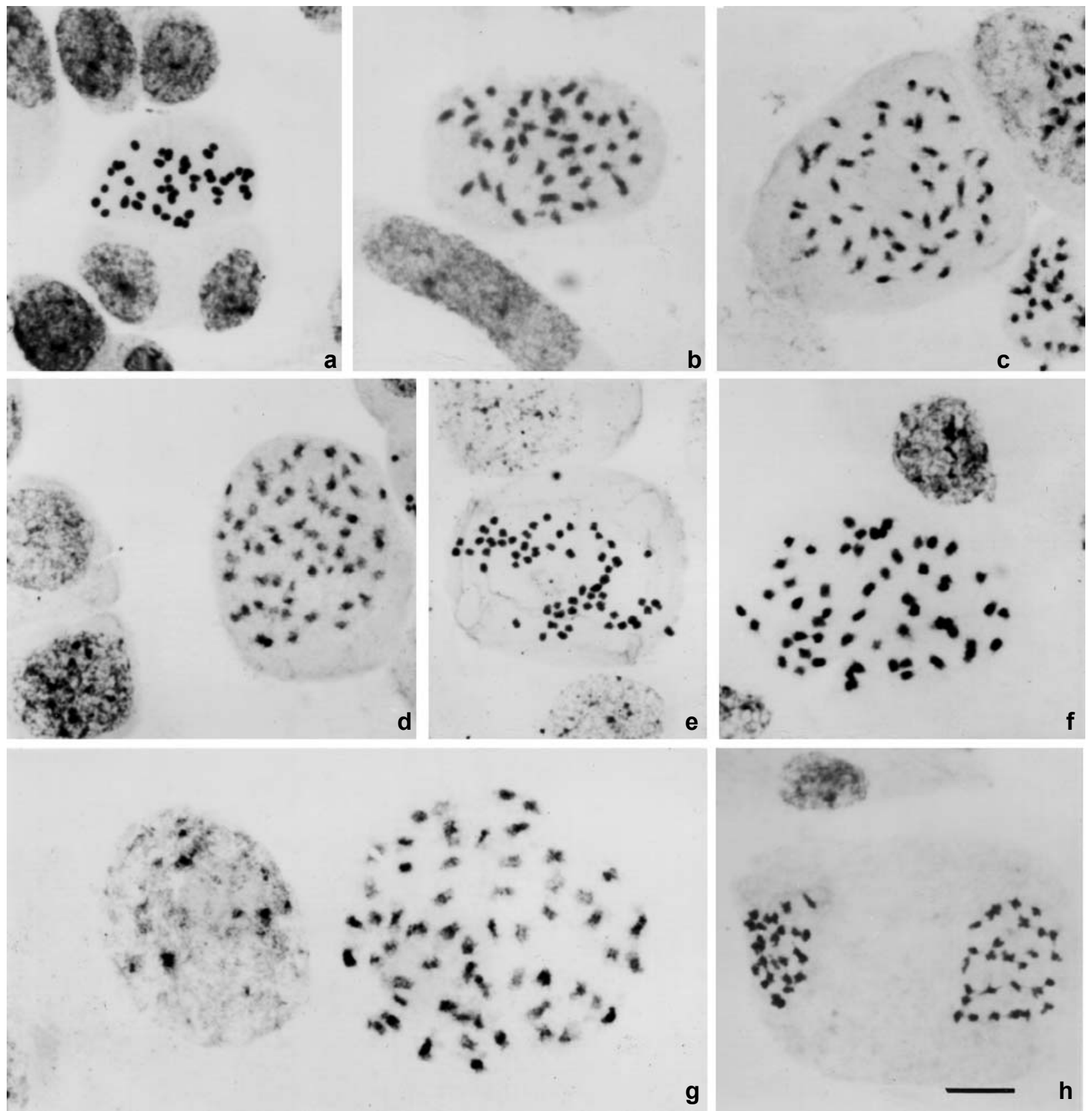

Figure 4 - Chromosome complements and interphase nuclei of orchid species of the subtribe Oncidiinae: (a) mitotic metaphase and interphase nucleus of Rodriguezia bahiensis $(2 \mathrm{n}=42) ;(\mathbf{b})$ R. lanceolata $(2 \mathrm{n}=42) ;(\mathbf{c})$ Notylia lyrata $(2 \mathrm{n}=44) ;(\mathbf{d})$ Lockartia goyazensis $(2 \mathrm{n}=56)$, and $(\mathbf{e})$ Oncidium barbatum $(2 \mathrm{n}=56) ;(\mathbf{f})$ O. baueri $(2 \mathrm{n}=56) ;(\mathrm{g})$ O. aff. crispum $(2 \mathrm{n}=56)$, and $(\mathbf{h})$ meiotic prophase II of $O$. flexuosum $(\mathrm{n}=28)$. Bar represents $10 \mu \mathrm{m}$.

has not been possible to obtain copies of all of them, since some journals were very difficult to access.

Table II presents the complete list of cytologically known Cymbidioid species, including original data of the present work. These data are synthesized in Table III, which shows the chromosome numbers recorded within each genus in decreasing order of frequency. The most probable base number of each genus was also tentatively recognized. The base number was identified as one of the haploid number actually found in the genus that most parsimoniously explains the chromosome number variation found in the taxon and more related genera (Guerra, 2000). Based on this concept, it was possible to indicate the number that most probably represents the original haploid complement for each genus. The criterion of the "most frequent" chromosome number was accepted as an indicator of the base number only when it was well represented in the related genera. In many genera, such as Liparis, Eulophia and Odontoglossum, two or more numbers seemed equally probable and were provisorily maintained as base numbers, although only one of them should represent the primary base number of each genus. 

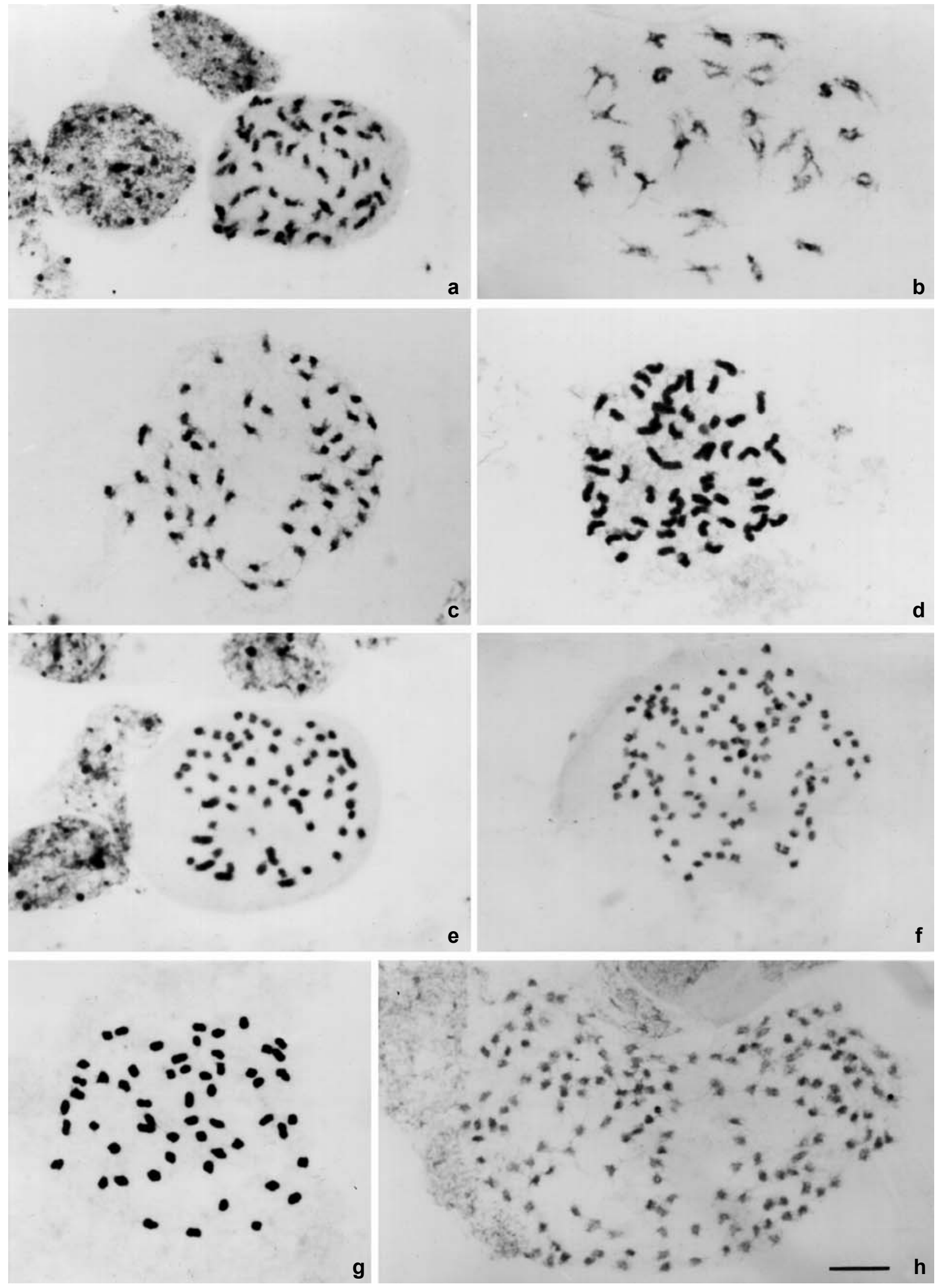

Figure 5 - Chromosome complements and interphase nuclei of Brazilian species of Oncidiinae: (a) Oncidium gravesianum $(2 \mathrm{n}=56)$; (b) diplotene of $O$. loefgrenii $\left(\mathrm{n}=28^{\mathrm{II}}\right)$; (c) Oncidium paranaense $(2 \mathrm{n}=56)$; (d) Brassia lawrenciana $(2 \mathrm{n}=60)$; (e) Miltonia flavescens $(2 \mathrm{n}=60)$. Observe eight larger chromosomes; (f) diakinesis of Oncidium varicosum $\left(\mathrm{n}=56^{\mathrm{II}}\right) ;(\mathrm{g})$ O. blanchetii $(2 \mathrm{n}=$ ca. 112$)$, and (h) O. aff. flexuosum $(2 \mathrm{n}=$ ca. 168$)$. Bar represents $10 \mu \mathrm{m}$. 


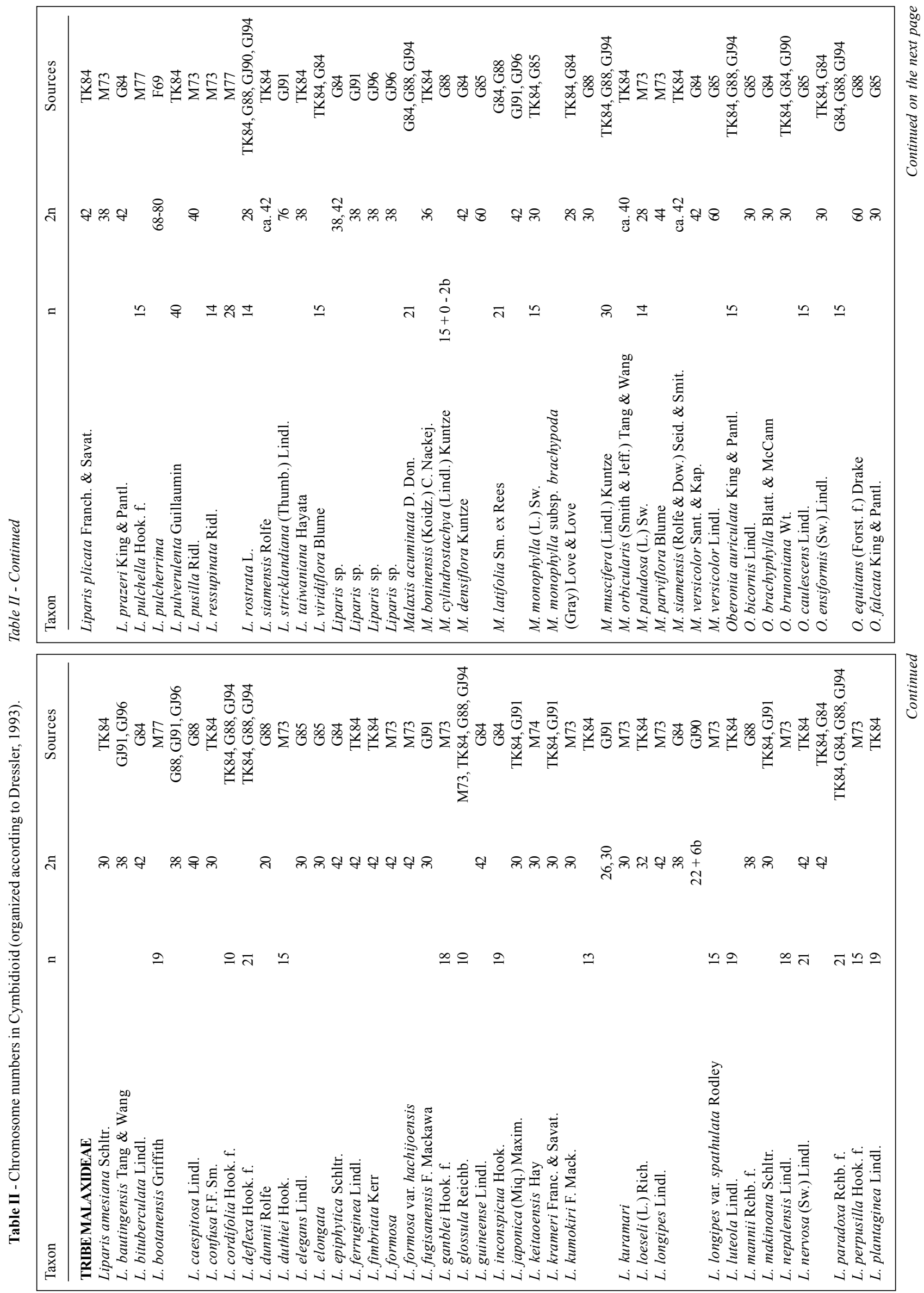




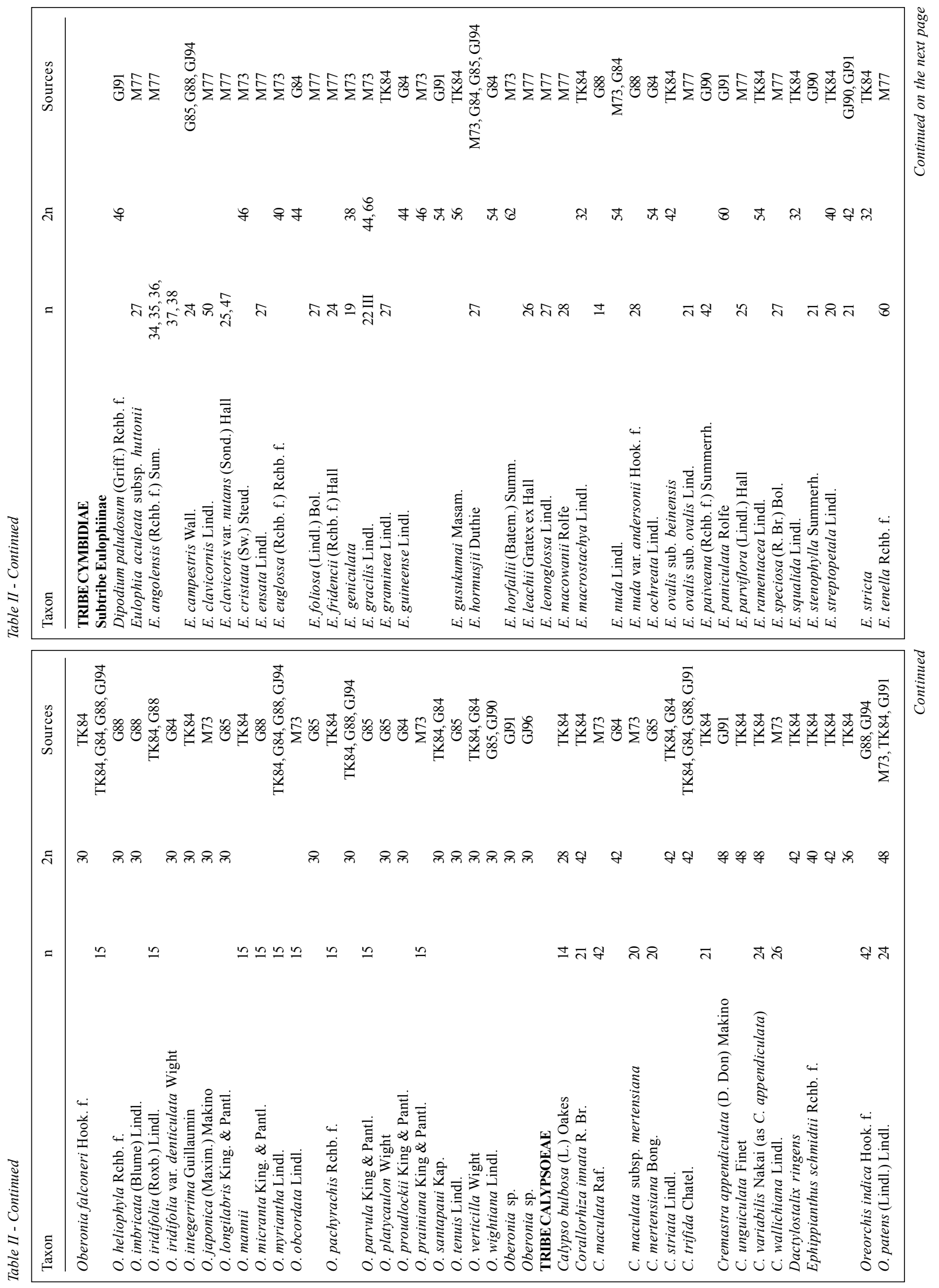




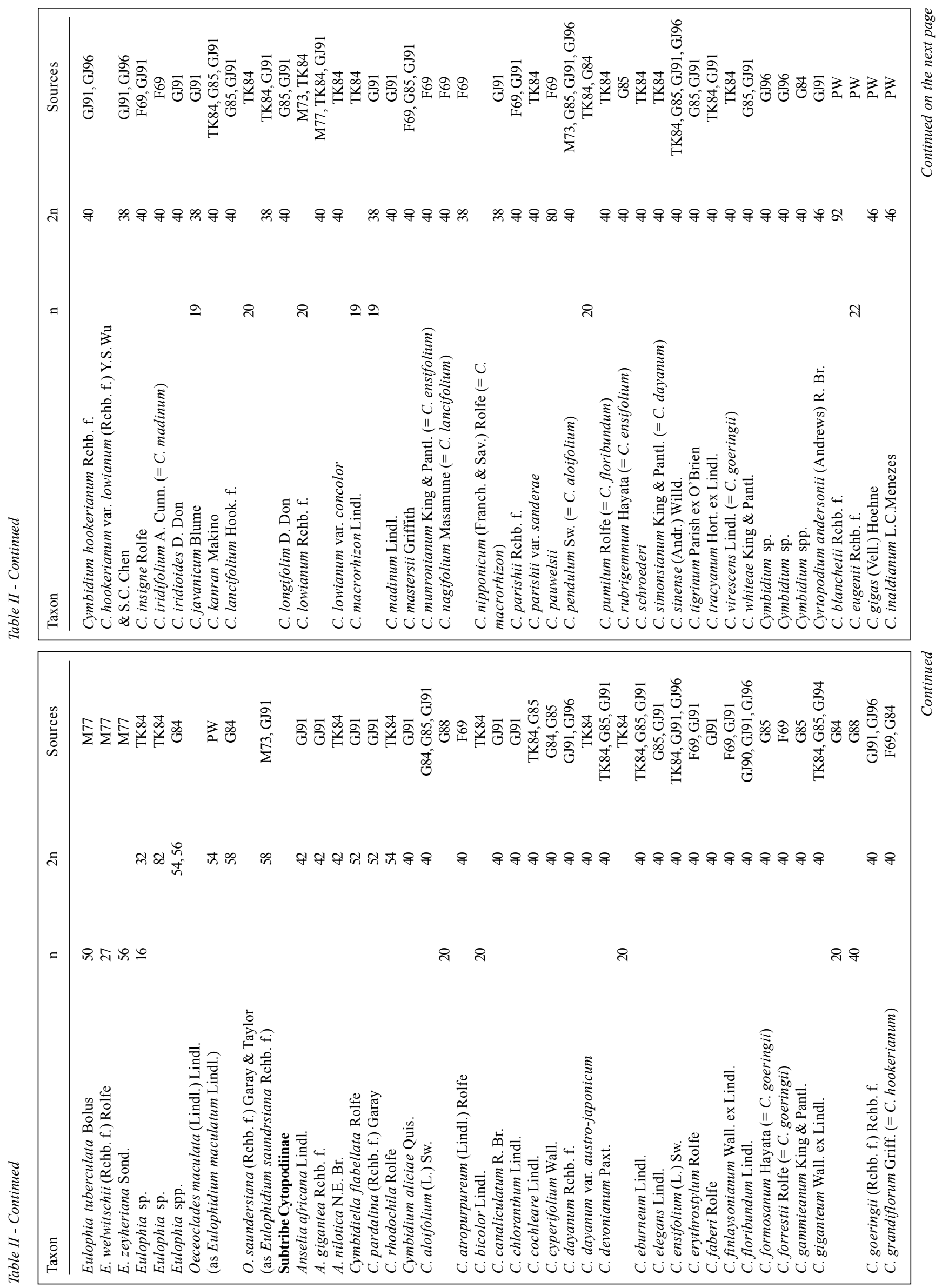




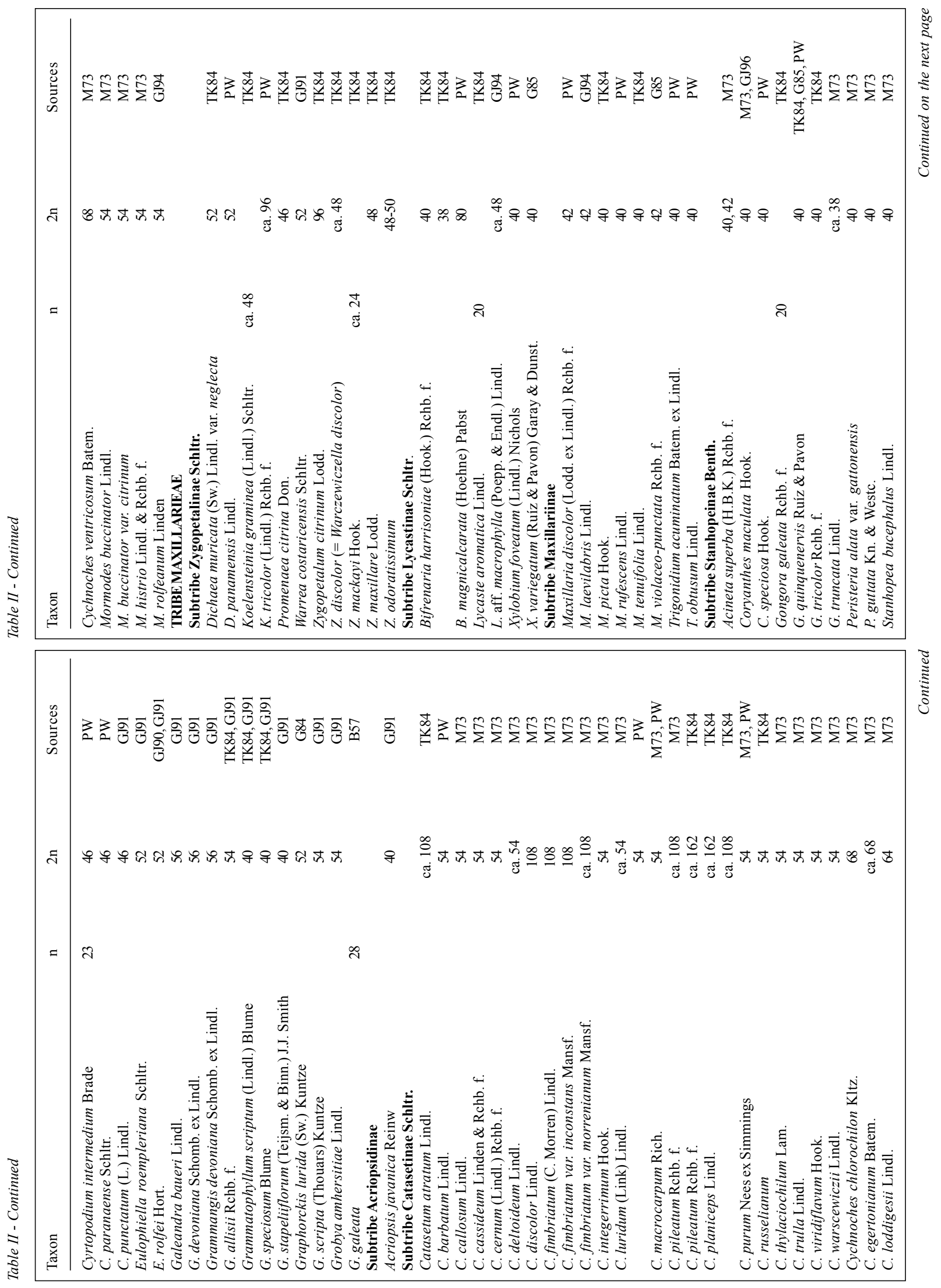




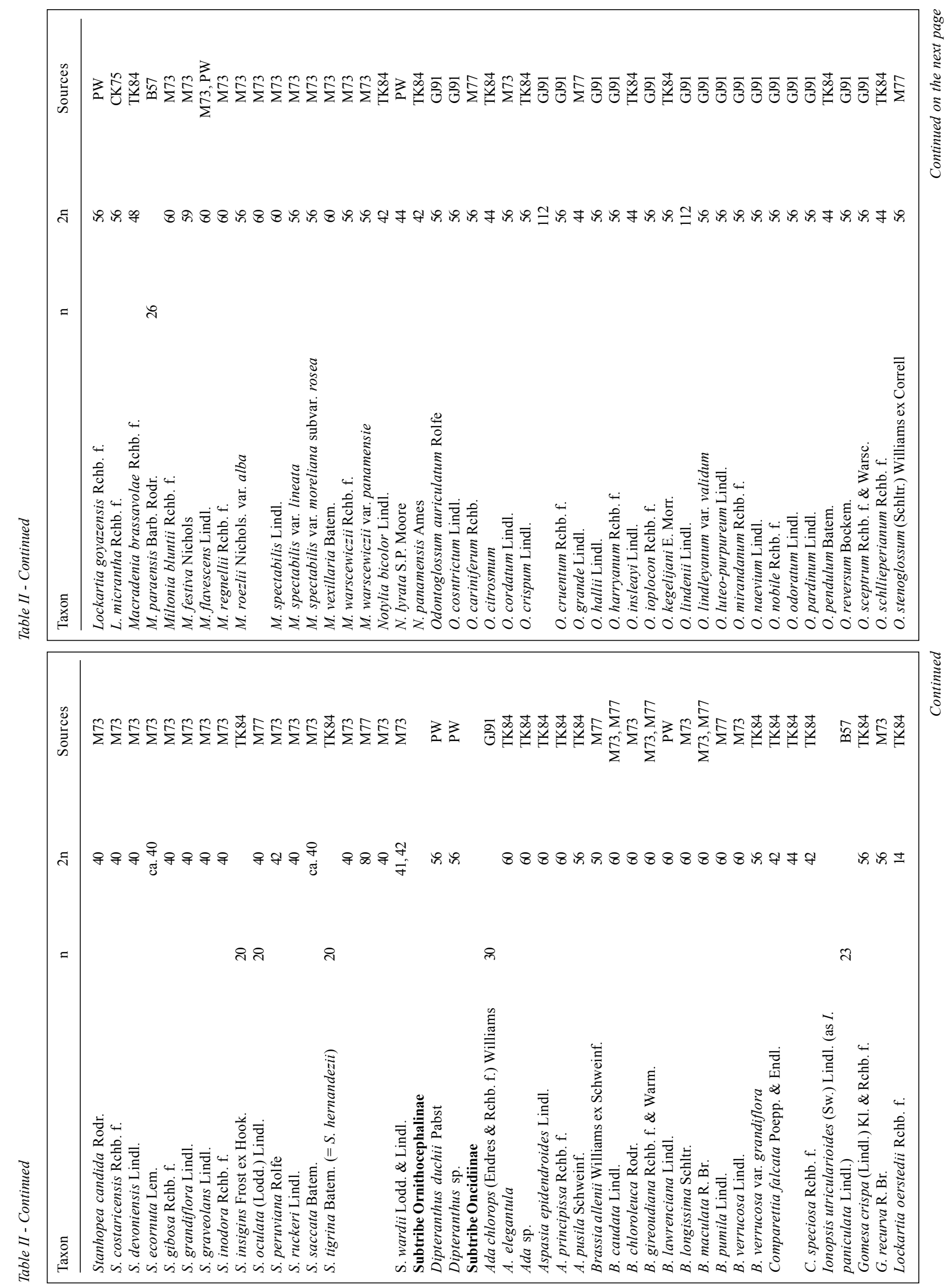




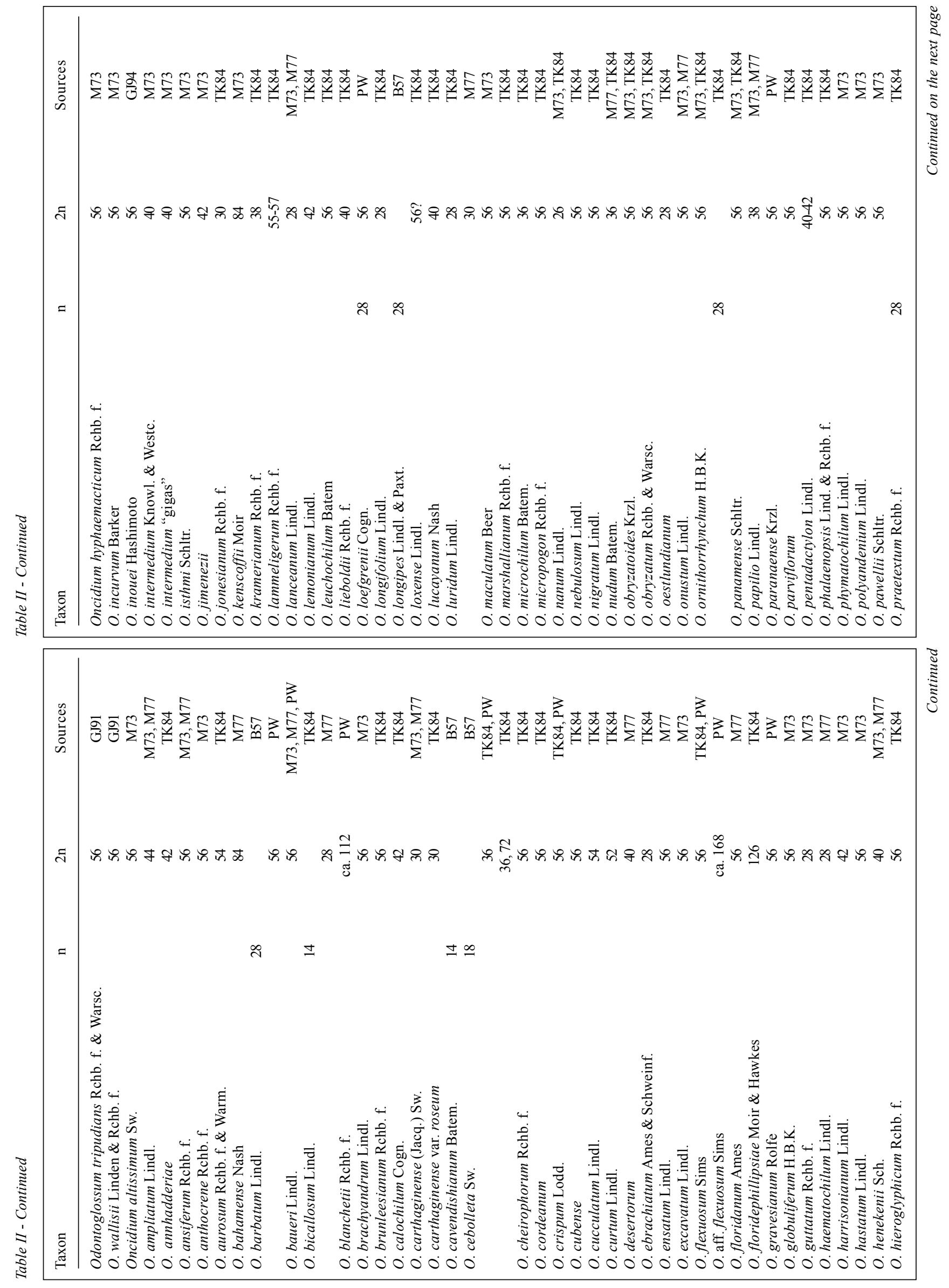




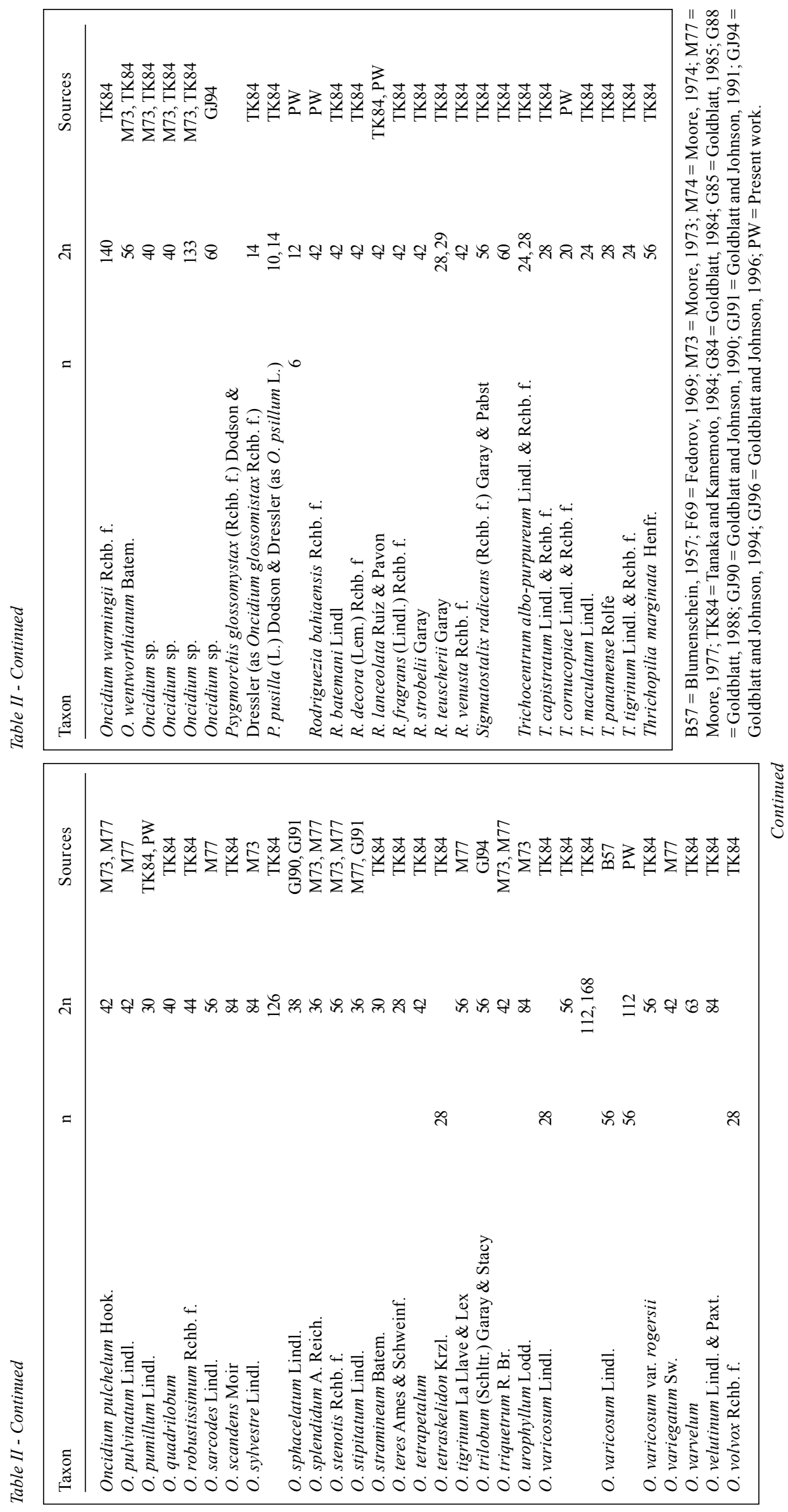


Some chromosome numbers registered in the literature were not included in Tables II and III because they clearly differed from other records for the same species or were incompatible with the records for the genus. For example, Blumenschein $(1957,1960 \mathrm{a})$ reported $\mathrm{n}=28$ in the pollen mitosis of four Catasetum species. However, in Jones and Daker's (1968) analysis of 21 taxa of this genus, including three of the four species reported by Blumenschein, none presented this number. Further in the present work, $2 n=54$, the most common number in the genus, was observed in four species (Figures 1h,i and 2a-c) and 2n=ca. 108 in two populations of Catasetum discolor. All the counts considered as probably wrong were presented in a separate table (Table IV) and were not included in the discussion.

Numerical variations related to a single species were excluded from Table II, wherever other references confirmed only one of these numbers. In Oncidium microchilum, for example, Sinotô $(1962,1969)$ and Charanasri

Table III - Chromosome numbers and probable base numbers of tribes, subtribes and genera of Cymbidioid (sensu Dressler, 1993). Chromosome numbers are ordered from the more to the less frequent. Numbers conected with a line have equal frequencies.

\begin{tabular}{|c|c|c|}
\hline $\begin{array}{l}\text { Tribes and subtribes with the number } \\
\text { of genera/species known }\end{array}$ & $\begin{array}{l}\text { Genera with the number of } \\
\text { species known/ analyzed }\end{array}$ & $\begin{array}{l}\text { Chromosome numbers reported and more } \\
\text { probable base numbers (underlined) }\end{array}$ \\
\hline \multicolumn{3}{|l|}{ Tribe Malaxideae (6/960) } \\
\hline & Liparis Rich. (350/52) & $21,15,19,10-20,14-18-40,11-13-$ ca.21-28-34-38 \\
\hline & Malaxis Sw. (300/13) & $21,15-30,14,18-$ са. $20-22$ \\
\hline & Oberonia Lindl. (300/30) & 15,30 \\
\hline \multicolumn{3}{|l|}{ Tribe Calypsoeae (9/35) } \\
\hline & Calypso Salisb. (1/1) & 14 \\
\hline & Corallorhiza Chatelain (15/5) & $21,20-42$ \\
\hline & Cremastra Lindl. (7/4) & 24,26 \\
\hline & Dactylostalix Rchb. f. (1/1) & 21 \\
\hline & Ephippianthus Rchb. f. (1/1) & $18-20-21$ \\
\hline & Oreorchis Lindl. $(9 / 2)$ & $24-42$ \\
\hline \multicolumn{3}{|l|}{ Tribe Cymbidieae (28/732) } \\
\hline \multicolumn{3}{|l|}{ Subtribe Eulophiinae (6/264) } \\
\hline & Dipodium R. Br. (20/1) & 23 \\
\hline & Eulophia R. Br. (200/39) & $\begin{array}{c}27,28,16-21,24,20-25,22-30,14-26-31-33- \\
34-35-36-37-38-40-41-44-47-48-50-56-60\end{array}$ \\
\hline & Oeceoclades Lindl. (31/2) & 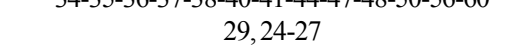 \\
\hline \multicolumn{3}{|l|}{ Subtribe Cyrtopodiinae (12/139) } \\
\hline & Anselia Lindl. (2/3) & 21 \\
\hline & Cymbidiella Rolfe $(3 / 3)$ & 26,27 \\
\hline & Cymbidium Sw. (45/40) & $20,19,40,43 / 2,57 / 2$ \\
\hline & Cyrtopodium R. Br. (30/8) & $23,22-46$ \\
\hline & Eulophiella Rolfe (2/2) & 26 \\
\hline & Galeandra Lindl. $(25 / 1)$ & 28 \\
\hline & Grammangis Rchb. f. $(2 / 2)$ & $27-28$ \\
\hline & Grammatophyllum Blume (12/3) & 20 \\
\hline & Graphorkis Thouars $(5 / 2)$ & $26-27$ \\
\hline & Grobya Lindl. (3/2) & $27-28$ \\
\hline \multicolumn{3}{|l|}{ Subtribe Acriopsidinae (1/6) } \\
\hline & Acriopsis Blume (6/1) & 20 \\
\hline \multicolumn{3}{|l|}{ Subtribe Catasetinae (5/194) } \\
\hline & Catasetum Rich. ex Kunth (100/19) & 27,54, ca. 54, ca. $27-81$ \\
\hline & Cychnoches Lindl. (23/4) & 34, 32-ca. 34 \\
\hline & Mormodes Lindl. (60/3) & 27 \\
\hline \multirow{2}{*}{\multicolumn{3}{|c|}{ Tribe Maxillarieae (157/2.573) }} \\
\hline \multicolumn{2}{|l|}{ Subtribe Zygopetalinae (30/331) } & \\
\hline & Dichaea Lindl. (55/2) & 26 \\
\hline & Koelensteinia Rchb. f. $(16 / 2)$ & ca. 48 \\
\hline & Promenaea Lindl. (14/1) & 23 \\
\hline & Warrea Lindl. (4/1) & 26 \\
\hline & Zygopetalum Hook. (15/5) & ca. $24,48,25$ \\
\hline \multicolumn{3}{|l|}{ Subtribe Lycastinae (8/127) } \\
\hline & Bifrenaria Lindl. (24/2) & $19-20-40$ \\
\hline & Lycaste Lindl. (49/2) & 20 -ca. 24 \\
\hline & Xylobium Lindl. (29/2) & 20 \\
\hline \multicolumn{3}{|l|}{ Subtribe Maxillariinae (8/472) } \\
\hline & Maxillaria Ruiz \& Pavon (420/6) & $20-21$ \\
\hline & Trigonidium Lindl. (14/2) & 20 \\
\hline
\end{tabular}


Table III - Continued

\begin{tabular}{|c|c|c|}
\hline $\begin{array}{l}\text { Tribes and subtribes with the number } \\
\text { of genera/species known }\end{array}$ & $\begin{array}{l}\text { Genera with the number of } \\
\text { species known/ analyzed }\end{array}$ & $\begin{array}{l}\text { Chromosome numbers reported and more } \\
\text { probable base numbers (underlined) }\end{array}$ \\
\hline \multicolumn{3}{|l|}{ Subtribe Stanhopeinae (22/248) } \\
\hline & Acineta Lindl. (20/1) & $20-21$ \\
\hline & Coryanthes Hook. (20/2) & 20 \\
\hline & Gongora Ruíz \& Pavon (50/4) & 20 , ca. 19 \\
\hline & Peristeria Hook. (15/2) & 20 \\
\hline & Stanhopea Frost ex Hook. (55/17) & 20, ca. $20-21,40$ \\
\hline \multicolumn{3}{|l|}{ Subtribe Ornithocephaliinae (14/76) } \\
\hline & Dipteranthus Barb. Rodr. (8/2) & 28 \\
\hline \multicolumn{3}{|l|}{ Subtribe Oncidiinae (47/1231) } \\
\hline & Ada Lindl. (15/3) & 30 \\
\hline & Aspasia Lindl. (8/3) & 30,28 \\
\hline & Brassia R. Br. (35/9) & $30,26,25$ \\
\hline & Comparettia Poepp. \& Endl. (10/2) & 21,22 \\
\hline & Gomesa $\operatorname{R.Br}$. (13/2) & 28 \\
\hline & Ionopsis Kunth (3/1) & 23 \\
\hline & Leochilus Knowles \& West. (10/3) & 21,24 \\
\hline & Lockartia Hook. (24/3) & 28,7 \\
\hline & Macradenia R. Br. (12/2) & $24-26$ \\
\hline & Miltonia Lindl. (25/8) & $30,28,59 / 2$ \\
\hline & Notylia Lindl. $(50 / 3)$ & 21,22 \\
\hline & Odontoglossum Kunth (140/28) & $28,22,56$ \\
\hline & Oncidium Sw. (420/113) & $\begin{array}{l}28,21,14,42,15-18,19-22-26-27- \\
56-84,13-30-63-70-57 / 2-63 / 2\end{array}$ \\
\hline & Sigmatostalix Reichb. (35/1) & $28-30$ \\
\hline & Psygmorchis Dodson \& Dressler (5/2) & $7,5,6$ \\
\hline & Rodriguezia Ruíz \& Pavon (40/8) & 21,14 \\
\hline & Trichocentrum Poepp \& Endl. (30/6) & $12-14,10$ \\
\hline & Trichopilia Lindl. (30/1) & 28 \\
\hline
\end{tabular}

et al. (1973) registered $2 \mathrm{n}=36,37$. As the number $2 \mathrm{n}=$ 37 was not found in any species of Oncidium and $2 n=36$ was confirmed by other authors for this species, $2 n=37$ was excluded from Table II. The number $2 \mathrm{n}=41$ for Eulophia euglossa was also removed because it was described as an occasional trisomy besides the normal number $2 n=40$ (ar-Rushdi, 1971). Similarly, numbers attributed to B chromosomes, like the reference of Aoyama and Tanaka (1988) for a single individual with $2 \mathrm{n}=39+$ 5Bs of Cymbidium javanicum and $2 \mathrm{n}=38+1$ in $C$. lancifolium, were excluded. Occasional triploids, like that referred to $C$. javanicum $(2 \mathrm{n}=57)$ by the same authors above, were not considered significant for the cytotaxonomic evaluation of the genus and were also excluded. All these counts were listed in Table IV for future evaluation. Some other seemingly incorrect counts were not excluded for a lack of documentation or a strong argument proving the error. Daker and Jones (1969), for example, suggested that counts with $2 n=42$ in the subtribe Stanhopeinae are "largely the result of detached satellites", but they admit that at least Stanhopea peruviana has $2 n=42$. In this case all the counts of $2 n=42$ were excluded in only $S$. grandiflora, $S$. inodora, $S$. oculata and $S$. tigrina, because other counts are known that confirm $2 \mathrm{n}=40$ for these species. In $S$. wardii and Acineta superba, the only records known were conserved $(2 \mathrm{n}=$ 41,42 and $2 n=40,42$, respectively). This "cleaning", albeit partial, reduced the importance of those numbers in the identification of the base number of Stanhopea and Stanhopeinae.

\section{Karyological evolution}

The chromosome number variability observed in orchids is not only very extensive but also difficult to relate to a single base number. Cytotaxonomical analysis can be better understood in genera with great cytological diversity, which often correspond to the genera with the highest number of species in the tribe or family, like Boronia in the tribe Boroniae, Rutaceae (Stace, 1995), Carex in Cyperaceae (Luceño, 1994), and Passiflora in Passifloraceae (Snow and MacDougal, 1993). In Cymbidioid, the largest genera are Oncidium and Maxillaria with about 420 species in each one. Maxillaria is very poorly investigated (only six species), whereas Oncidium is the genus most extensively studied of the phylad (117 species). Chromosome number variability in Oncidium is also quite representative of the group. The known haploid numbers are n $=13,14,15,18,19,20,21,22,25,26,27,28,29,30,36$, $42,56,63,70,84$. This variation is clearly dominated by the polyploid series $n=14,21,28,42,56,63,70,84$. The great majority $(64.8 \%)$ are ortoploid with $n=14,21$ or 28 , of which $46 \%$ display $n=28$. These data strongly suggest $\mathrm{x}_{1}=7$ as the primary base number for the genus, al- 
Table IV - Cymbidioid species with uncertain chromosome numbers.

\begin{tabular}{|c|c|c|c|c|c|c|c|}
\hline Species & $\mathrm{n}$ & $2 n$ & Index & Species & $\mathrm{n}$ & $2 n$ & Index \\
\hline Aspasia principissa $\mathrm{Rchb}$. $\mathrm{f}$. & & 58 & TK84 & Liparis rostrata $\mathrm{L}$. & 15 & & TK84 \\
\hline Brassia lawrenciana var. longissima & & $52-56$ & TK84 & Malaxis monophylla (L.) Sw. & $15-17$ & & TK84 \\
\hline B. verrucosa Lindl. & & $52-58$ & TK84 & Miltonia flavescens Lindl. & & 56 & TK84 \\
\hline Calypso bulbosa (L.) Oakes & & 32 & TK84 & Oberonia caulescens Lindl. & 13 & & TK84 \\
\hline Catasetum atratum Lindl. & & 56 & TK84 & O. myriantha Lindl. & ca. 36 & & TK84 \\
\hline C. cernum (Lindl.) Rchb. f. & & 56 & TK84 & Odontoglossum citrosmum & & $44-48$ & TK84 \\
\hline C. hookeri Lindl. & & 56 & TK84 & O. grande & & $60 ?$ & TK84 \\
\hline C. macrocarpum L.C. Rich. & & 56 & TK84 & O. harryanum Rchb. f. & & 84 & GJ91 \\
\hline \multirow[t]{2}{*}{ Corallorhiza trifida Chatel } & & 38 & G84 & Oeceoclades maculata (Lind1.) Lindl. & & 48 & GJ90 \\
\hline & & 40 & G88 & Oncidium baueri Lindl. & & ca. 52 & TK84 \\
\hline Cremastra appendiculata (D. Don) Makino & & 42 & G88 & O. cartagenense (Jacq.) Sw. & & 28 & TK84 \\
\hline C. unguiculata & & 50 & TK84 & O. cebolleta $\mathrm{Sw}$. & & 34 & TK84 \\
\hline C. variabilis Nakai & & 46 & TK84 & O. cheirophorum Rchb. f. & & ca. 48 & TK84 \\
\hline Cymbidium aloifolium Sw. & 16 & 32 & TK84 & O. guttatum Rchb. f. var. olivaceum & & 32 & TK84 \\
\hline C. bicolor Lindl. & & 42 & GJ90 & O. haematochilum Lindl. & & 40 & TK84 \\
\hline \multirow[t]{2}{*}{ C. cyperifolium Lindl. } & & 42 & TK84 & O. inouei Hashimoto & & 52 & GJ94 \\
\hline & & 36,40 & GJ96 & O. lanceanum Lindl. & 13 & $26(24)$ & TK84 \\
\hline C. eburneum Lindl. & & 38 & GJ91, GJ96 & O. lammerigerum & & $55-47$ & TK84 \\
\hline \multirow[t]{2}{*}{ C. faberi Rolfe } & & 43,44 & GJ96 & O. lieboldii & & 42 & TK84 \\
\hline & & 42 & GJ91 & O. luridum Lindl. & & 32 & TK84 \\
\hline C. floribundum Lindl. & & 38 & GJ91 & & & $28+2 f$ & TK84 \\
\hline C. goeringii (Rchb. f.) Rchb. f. & & 38 & GJ91 & O. macrantum Lindl. & & $50-57$ & TK84 \\
\hline C. hookerianum Rchb. f. & & 38 & GJ91 & O. microchilum Batem. & & 37 & TK84 \\
\hline C. javanicum Blume & & 43,57 & GJ91 & O. sphacelatum Lindl. & & 57 & GJ91 \\
\hline C. kanran Makino & & 40,41 & GJ91 & & & 56 & M73 \\
\hline C. lancifolium Hook. f. & & 39 & GJ91 & O. splendidum A. Reich. & & 34 & TK84 \\
\hline C. lowianum Reichb. f. & $9-10$ & & TK84 & O. stipitatum Lindl. & & 28 & TK84 \\
\hline C. sikkimense Hook. f. & 19 & & TK84 & O. stramineum Batem. & & 28 & TK84 \\
\hline Cymbidium $\mathrm{sp}$. & & 42 & GJ96 & O. tigrinum & & 54 & TK84 \\
\hline Eulophia clavicornis Lindl. & 47 & & TK84 & O. variegatum $\mathrm{Sw}$. & & 40 & TK84 \\
\hline E. euglossa (Rchb. f.) Rchb. f. & & 41 & TK84 & O. warmingii Rchb. f. & & 150 & TK84 \\
\hline E. ovalis Lindl. subsp. bainensis (Rolfe) Hall & & 41 & TK84 & Oreorchis patens (Lindl.) Lindl. & 50 & & TK84 \\
\hline Gongora quinquenervis Ruíz \& Pavon & & 38,40 & TK84 & Rodriguezia teuscherii Garay & & 29 & TK84 \\
\hline Grammatophyllum scriptum (Lindl.) Blume & & 38 & G88 & Stanhopea grandiflora Lindl. & & 38,42 & TK84 \\
\hline Liparis krameri Franc. \& Savat. & & 36 & GJ94 & S. inodora Rchb. f. & & 42 & TK84 \\
\hline Liparis nervosa (Sw.) Lindl. & & 40 & GJ91, GJ96 & S. oculata (Lodd.) Lindl. & & 42 & TK84 \\
\hline L. paradoxa Rchb. f. & 18 & & TK84 & S. tigrina Batem. $(=S$. hernandezii $)$ & & 41,42 & TK84 \\
\hline L. paradoxa $\mathrm{Rchb}$. f. & 18 & & TK84 & & & & \\
\hline
\end{tabular}

though this number is hypothetical, since no species of the genus is known with $\mathrm{n}=7$. Thus, most Oncidium species should be tetraploid $(n=14)$, hexaploid $(n=21)$ or octoploid $(n=28)$. The diploids have not yet been found or were extinct, since the hexaploid $n=21$ could only arise from a cross between tetraploids $(n=14)$ and putative diploids $(\mathrm{n}=7)$ followed by polyploidization (Harlan and De Wet, 1975). Therefore, if the genus was originated from a tetraploid lineage, the hexaploid species could not belong to this same lineage and the genus would be artificial. The same may have occurred in Rodriguezia, with $2 \mathrm{n}=28$ (Sinotô, 1962) and 2n = 42 (Figure 4a,b, Table II).

When the subtribe Oncidiinae is considered as a whole, the variation of chromosome numbers seems very similar to that of the genus Oncidium (Figure 6), with the numbers $n=21$ and $n=28$ prevailing, suggesting that the other genera have a common ancestor with Oncidium. The subtribe also has the smallest chromosome numbers of the family: $\mathrm{n}=7$ in Lockartia and $\mathrm{n}=5,6$ and 7 in Psygmorchis. In three populations of $P$. pusilla studied in the present work,
$2 \mathrm{n}=12$ and $\mathrm{n}=6$ were always found (Figure $3 \mathrm{~g}$ ), disagreeing with records of Dodson (1957a,b) and Kugust (1966, apud Tanaka and Kamemoto, 1984). Further analyses in other Lockartia species would be important to verify whether the polyploid series observed in Oncidium is also repeated in this genus. The only Lockartia species analyzed in the present work exhibited $2 n=56$ (Figure $4 d$ ), which coincides with the previous reports of Charanasri and Kamemoto (1975) for L. micrantha. These data support the inclusion of Lockartia in Oncidiinae, in opposition to the assumption of Freudenstein and Rasmussen (1999) based on the absence of leaf articulation in this genus.

Considering the polyploid series observed in $\mathrm{On}^{-}$ cidium and Oncidiinae in general, it is reasonable to suppose that $\mathrm{x}=7$ would be the primary base number of the subtribe, as suggested by Charanasri and Kamemoto (1975). In this case, most Oncidiinae genera would have hexaploid (Comparettia, Notylia) or octoploid origin (Aspasia, Gomesa, Miltonia, Sigmatostalix, Trichopilia). The number $\mathrm{n}=7$ may represent the original haploid complement of 


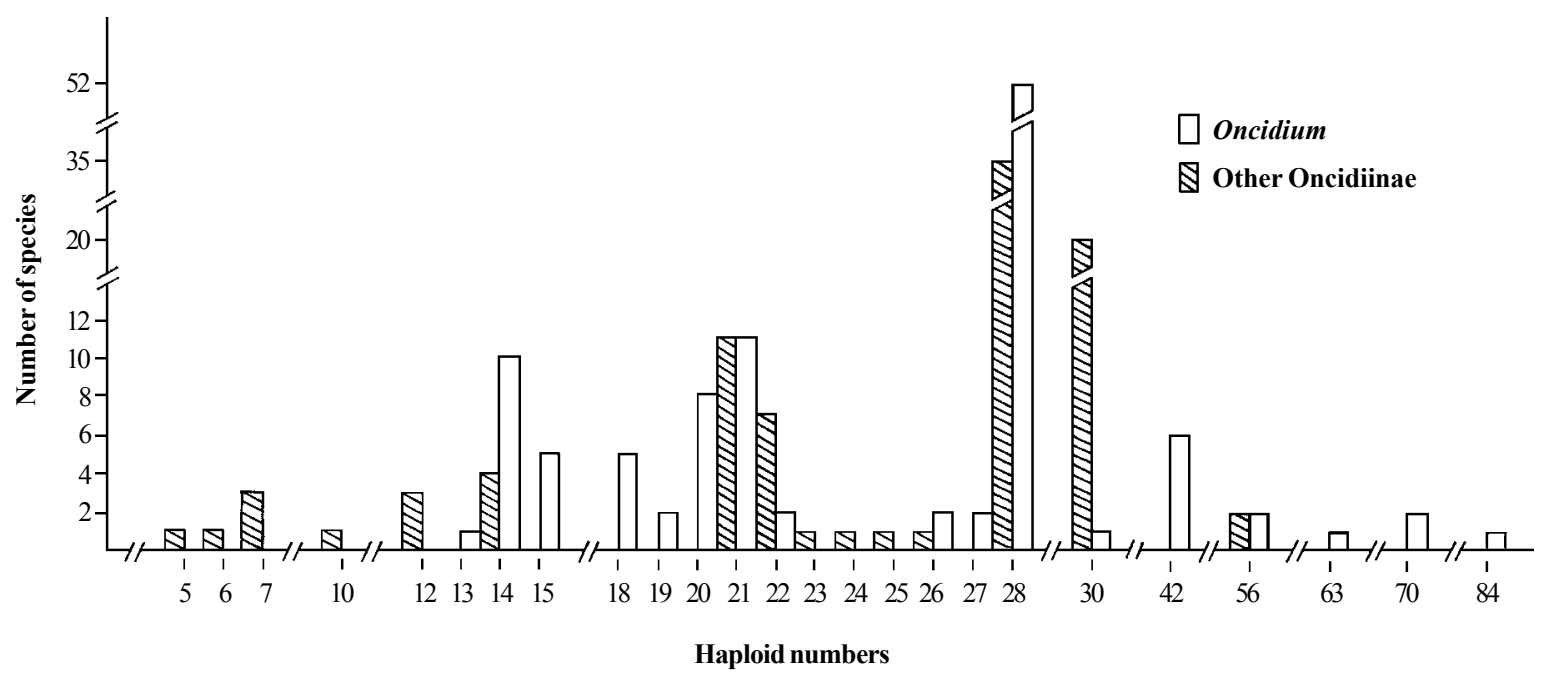

Figure 6 - Chromosome number variation among Oncidium species compared to other Oncidiinae.

Orchidaceae, found nowadays in very few species. Successive cycles of polyploidy would have originated tetraploid $(\mathrm{n}=14)$, hexaploid $(\mathrm{n}=21)$ and octoploid $(\mathrm{n}=28)$ lineages, some of which gave origin to entirely polyploid genera (Table III). As polyploidy is quite a recurrent phenomenon in the evolution of angiosperms (Soltis and Soltis, 1995; Leitch and Bennett, 1997), it is very probable that higher polyploids arose de novo many times in a number of other genera.

The only cytologically known genera distant from the series n =7, 14, 21, 28 in Oncidiinae are Ionopsis, Macradenia and Trichocentrum. In Ionopsis, there is only one record with $\mathrm{n}=23$, whereas in Macradenia there are data for one species with $n=26$ and another with $2 n=48$ chromosomes (Blumenschein, 1957; Sinotô, 1962). In Trichocentrum, there are records of five species with $2 n=28$ and $2 \mathrm{n}=24$, besides the present count with $2 \mathrm{n}=20$ in $T$. cornucopiae (Figure $3 \mathrm{~h}$ ). Trichocentrum may have a dysploid series with $n=14,12,10$, but the available data are still very fragmented. Chase (1986), based on a combination of floral, vegetative and chromosomal characters, suggested that Trichocentrum could represent an independent evolutionary lineage distinct from the other genera of Oncidiinae.

The present interpretation for the karyological evolution of Oncidium/Oncidiinae conflicts directly with that of Chase and collaborators (Chase, 1986, Chase and Pippen, 1988; Chase and Olmstead, 1988; Chase and Palmer, 1992). These authors observed that the most primitive representatives of the subtribe had higher chromosome numbers, whereas Psygmorchis and Lockartia, with more derived morphological characters, like laterally flattened leaves, displayed the lowest chromosome numbers. Therefore they concluded that Oncidium and some Oncidiinae have the original chromosome numbers $(\mathrm{x}=28,30)$ which, through successive dysploidy, originated the low numbered species with $\mathrm{n}=7-5$. This conclusion was supported by isoenzymatic evidence from representatives of this group, which almost always exhibited a single locus for each isozyme (Chase and Olmstead, 1988), like dysploids. However, the isoenzymatic analysis of several other definitely polyploid taxa also displayed a similar pattern (Haufler, 1987), suggesting that it is not an accurate indicator of ploidy level (Soltis et al., 1992).

The present interpretation is that the original stock was diploid and had been progressively substituted by polyploids. As polyploids often have very slow evolution rates, they may conserve more primitive characters (Stebbins, 1971), as observed in many present day polyploids of Oncidiinae and other groups (Guerra, 2000). This same reasoning is also applied to other primitive and highly polyploid genera of orchids, such as Neuwiedia and Apostasia (Okada, 1988). On the other hand, diploids and recent polyploids exhibit more derived characters in different parallel evolutionary lines, as Dipteranthus in Ornithocephalinae (Williams et al., 1994) and Lockartia in Oncidiinae (Chase, 1986; Freudenstein and Rasmussen, 1999).

The chromosome analysis of Oncidiinae helps one to understand the seemingly unrelated numbers of the remaining members of tribe Maxillarieae (Table III). Thus, the genera of Lycastinae, Maxillariinae and Stanhopeinae, clearly based on $n=20$, may be derived by descending dysploidy from a hexaploid lineage with $n=21$. Ornithocephalinae, karyologically known only from two counts in the present work for the genus Dipteranthus with $2 n=56$ (Figures 3c,d), coincides with the base number of most Oncidiinae genera, supporting its affinity with that subtribe (Chase and Pippen, 1988). Only the subtribe Zygopetalinae seems to be more diversified in the hexaploid-octoploid level $(\mathrm{n}=26,24 / 48,23)$.

The data from Table III suggest the existence of three groups: a larger group (Oncidiinae and Ornithocephalinae), 
evolved from the base number $\mathrm{x}_{1}=7$ and followed by successive cycles of polyploidy and secondary dysploidy; a second group (Lycastinae, Maxillariinae and Stanhopeinae), which is made up of hexaploids with $\mathrm{n}=21$ that by dysploid reduction led to a secondary base number $\mathrm{x}_{2}=20$, and a third group (Zygopetalinae), with a putative base number $\mathrm{x}_{2}$ $=24$ or 26 and no clear relationship with the polyploid series based on $x_{1}=7$. Morphologically, Stanhopeinae and Lycastinae share in common the presence of plicate leaves and elaborated pollination mechanisms (van der Pijl and Dodson, 1966), whereas Oncidiinae and Ornithocephalinae have in common the absence of "sunken glandular trichomes", found in Maxillariinae, Lycastinae and Stanhopeinae (Toscano de Brito, 1998).

In the other tribes of Cymbidioid the best represented chromosome numbers are $\mathrm{n}=15,21$ in Malaxideae, $\mathrm{n}=$ 14, 21 in Calypsoeae, and $n=27$ in Cymbidieae. In Malaxideae, although $n=15$ is a very common number, $n=14$ has also been found at least in Liparis and Malaxis. In Liparis, the cytotaxonomic interpretation is made difficult by an apparent secondary polyploid series based on $\mathrm{x}=10(\mathrm{n}=$ $10,20,40)$. What is particularly impressive is the high frequency of species with $n=15$ in the three genera of Malaxideae, a very rare haploid number in other Cymbidioid (see Table II). Although Malaxideae is the second largest Cymbidioid tribe, it is notably little known, with less than $10 \%$ of its species investigated cytologically. In Calypsoeae, $\mathrm{n}=$ 14 has only been found in Calypso, with $\mathrm{n}=21$ prevailing in the other genera. If these numbers have a evolutionary history similar to that observed in Oncidium, probably they also have or have had representatives with $\mathrm{n}=7$.

In the tribe Cymbidieae, there is a higher diversity of chromosome numbers, in agreement with the polyphylie observed on the basis of morphological (Freudenstein and Rasmussen, 1999) and molecular evidence (Cameron et al., 1999). The main haploid numbers are $n=27$ and 23 in the subtribe Eulophiinae, $n=21,20, n=28,27$ in the subtribe Cyrtopodiinae, $\mathrm{n}=20$ in a single species of Acriopsidinae, and $n=27$ and $n=34$ in Catasetinae. In general the subtribe Eulophiinae is cytologically represented by Eulophia, which displays the second largest variation in chromosome numbers known in the phylad. In this genus, a polyploid series based on $\mathrm{x}=7(\mathrm{n}=14,21,28,35,56)$ is also represented, with the octoploid level $(\mathrm{n}=28,27)$ strongly dominant. In Oeceoclades, the only two species analyzed are also octoploids, while in Dipodium the only record $(n=23)$ is probably a hexaploid. Poggio et al. (1986), analyzing the meiotic behavior of several species of Eulophia with $\mathrm{n}=$ 21 , observed the frequent secondary association of bivalent three-to-three, suggesting that it would be a remaining homeology of the hexaploid condition with $\mathrm{x}=7$.

In Cyrtopodiinae, the most studied genera are Cymbidium with $\mathrm{x}=20$ and Cyrtopodium with $\mathrm{x}=23$. In the present work original data are supplied for six species of Cyrtopodium, one with $\mathrm{n}=22$ (Figure $1 \mathrm{~b}$ ), four with $\mathrm{n}=$ 23 (Figure 1c-e) and one with $\mathrm{n}=46$ (Figure $1 \mathrm{~g}$ ), reinforc- ing the importance of $\mathrm{x}=23$ in the genus. Cyrtopodium eugenii with $\mathrm{n}=22$ is morphologically distinguished from other species of Cyrtopodium by the presence of an inflorescence in raceme, whereas others generally present inflorescence in panicle. The numbers $n=28,27$ and 26 are represented in six of ten genera studied of Cyrtopodiinae and $n=21,20$ dominate in another three, once again suggesting a polyploid series with base in $\mathrm{x}=7$, followed by descending dysploidy. The genus Cymbidium is notable for its constancy in chromosome number $(n=20)$, except the species of subgenus Jensoa (sensu Christopher and Cribb, 1984), with $2 \mathrm{n}=38$ (Aoyama and Tanaka, 1988). According to Freudenstein and Rasmussen (1999) Cymbidium is a member of the Vandoid phylad while Jensoa is part of the large epidendroid polytomy, since Jensoa shows later antera bending and lacks other features such as two pollinia or the presence of endocarpic trichomes.

In Catasetinae, of the three cytologically known genera, Catasetum and Mormodes show $\mathrm{x}=27$, whereas Cycnoches presents $\mathrm{x}=34$. Of the five species of Catasetum studied in the present work, four showed $2 n=54$ and one $2 \mathrm{n}=108$ (Figures $1 \mathrm{~h}, \mathrm{i}$, and $2 \mathrm{a}, \mathrm{c}$ ), confirming $\mathrm{x}=$ 27 for the genus. Although Catasetinae and the genus Cyrtopodium display the same pollination syndrome and form a monophyletic group based on cpDNA restriction sites (Chase and Hills, 1992), they are not clearly related karyologically.

As a whole, the great majority of Cymbidioid are ortoploids of the series $n=7,14,21,2835,42,56,84$, or dysploids involving simple reductions. Compared to other large families of angiosperms, such as Poaceae (Hunziker and Stebbins, 1986) or Asteraceae (Watanabe et al., 1995), Orchidaceae stands out for the scarcity of representative diploids, where the Cymbidioid phylad is a very good example. These data suggest that the phylad, and consequently the family, may be older than is generally admitted (Garay, 1972), there having been sufficient time for diploids to be widely substituted by polyploids.

\section{Chromosome numbers and habitat variations}

In plants, the conquest of new habitats is often related to the occurrence of polyploidy (Stebbins, 1966). Frequently, polyploid races are associated to more extreme environmental conditions (Ehrendorfer, 1970; De Wet, 1986). In the orchid Anacamptis pyramidalis (L.) Rich., for example, the polyploid cytotypes are more adapted to regions with geologic formation different from those of diploid populations occurring in the same regions (Del Prete et al., 1991).

Although the orchids constitute a paleopolyploid group (Jones, 1974; Ehrendorfer, 1980), the reversion to terrestrial habitat of typically epiphytic species is apparently acquired more easily when an increase in ploidy level occurs. In the genus Pleione (Orchidaceae), for instance, all the epiphytics have $2 n=40$ while about $50 \%$ of the 
terrestrial or lithophytic species are higher polyploids (Stergianou, 1989). In the genus Laelia, subgenus Cyrtolaelia, the lithophytic species are generally allopolyploids (Blumenschein, 1960b). In the present work, a similar tendency was observed. All Catasetum and Oncidium species, with lithophytic or terrestrial habitats, presented high ploidy levels in comparison with epiphytic species (Table I). In Oncidium, $O$. aff. flexuosum with $2 \mathrm{n}=$ ca. 168 and lithophytic or terrestrial habitat is morphologically closely related to $O$. flexuosum with epiphytic habitat and chromosome number $2 \mathrm{n}=56$. The same occurs in $O$. blanchetii and $O$. varicosum $(2 \mathrm{n}=112)$. Likewise, Cyrtopodium blanchetii $(2 \mathrm{n}=92)$, with underground pseudobulbs, is tetraploid in relation to the other species with aerial pseudobulbs. Equally, Catasetum discolor, with terrestrial habitat, exhibited $2 \mathrm{n}=\mathrm{ca} .108$, while the other species had $2 n=54$. On the other hand, the population of Trigonidium acuminatum collected in a lithophytic incidental habitat, under strong anthropic pressure, presented the same ploidy level as T. obtusum $(2 \mathrm{n}=40)$, with epiphytic habitat.

\section{ACKNOWLEDGMENTS}

The authors are grateful to colleagues Maria José Gomes de Andrade for review of tables and Ana Christina Rabello Brasileiro and Natoniel Franklin de Melo for review and suggestion on English version. Research supported by $\mathrm{CNPq}$ (Conselho Nacional de Desenvolvimento Científico e Tecnológico) and FACEPE (Fundação de Amparo à Pesquisa de Pernambuco).

\section{RESUMO}

O clado Cymbidioid apresenta a mais ampla variação cromossômica numérica entre as orquidáceas, com registros desde $2 \mathrm{n}=10 \mathrm{em}$ Psygmorchis pusilla, até $2 \mathrm{n}=168$ em duas espécies de Oncidium. No presente trabalho, foram estudadas um total de 44 espécies pertencentes a 20 gêneros deste grupo, visando contribuir para esclarecer a evolução cariológica do grupo. Todas as plantas investigadas foram coletadas no Brasil, principalmente na Região Nordeste. A variação cromossômica encontrada foi semelhante àquela previamente registrada na literatura. Os números cromossômicos observados foram: $2 \mathrm{n}=54$ (subtribo Eulophiinae), $2 \mathrm{n}=44,46$ e 92 (subtribo Cyrtopodiinae), $2 \mathrm{n}=54$, ca. 108 (subtribo Catasetinae), $2 \mathrm{n}=52$, ca. 96 (subtribo Zygopetalinae), $2 \mathrm{n}=40,80$ (subtribo Lycastinae), $2 \mathrm{n}=40,42$ (subtribo Maxillariinae), $2 \mathrm{n}=40$ (subtribo Stanhopeinae), $2 \mathrm{n}=56$ (subtribo Ornithocephalinae) e $2 \mathrm{n}=12,20,30,36,42,44,56,112$, ca. 168 (subtribo Oncidiinae). Os núcleos interfásicos foram bastante variáveis entre os tipos cromocêntrico simples e cromocêntrico complexo, sem aparente valor citotaxonômico. Nos gêneros Catasetum e Oncidium, as espécies terrestres e rupícolas apresentaram níveis de ploidia superiores àqueles das espécies epifiticas, sugerindo que a poliploidia pode estar envolvida na capacidade de retornar a esse tipo de habitat. $\mathrm{O}$ número básico primário $\mathrm{x}=7$ parece estar associado aos números cromossômicos haplóides da maioria dos grupos de orquídeas Cymbidioid, sendo $\mathrm{n}=7$ observado apenas em dois gêneros atuais das Oncidiinae. Para cada tribo, subtribo e gênero são discutidos os números básicos prováveis e sua relação com o número básico primário $\mathrm{x}_{1}=7$ admitido para todo o clado.

\section{REFERENCES}

Aoyama, M. and Tanaka, R. (1988). Notable chromosome numbers in Cymbidium lancifolium, C. javanicum and C. nipponicum. J. Jpn. Bot. 63: 329-333

ar-Rushdi, A.H. (1971). Chromosomes of some West African orchids. Cytologia 36: 487-492.

Blumenschein, A. (1957). Estudos citológicos na família Orchidaceae. Doctoral thesis, Escola Superior de Agricultura "Luiz de Queiroz", Universidade de São Paulo, Piracicaba.

Blumenschein, A. (1960a). Número de cromossomas de algumas espécies de orquídeas. Publ. Cient. Univ. São Paulo 1: 45-50.

Blumenschein, A. (1960b). Estudo sobre a evolução no subgênero Cyrtolaelia (Orchidaceae). Livre-Docência thesis, Escola Superior de Agricultura "Luis de Queiroz", Universidade de São Paulo, Piracicaba.

Cameron, K.M., Chase, M.W., Whitten, W.M., Kores, P.J., Jarrell, D.C., Albert, V.A., Yukawa, T., Hills, H.G. and Goldman, D.H. (1999). A phylogenetic analysis of Orchidaceae: evidence from $R B C L$ nucleotide sequences. Am. J. Bot. 86: 208-224.

Charanasri, U. and Kamemoto, H. (1975). Additional chromosome numbers in Oncidium and allied genera. Am. Orchid Soc. Bull. 44: 686691.

Charanasri, U., Kamemoto, H. and Takashita, M. (1973). Chromosome numbers in the genus Oncidium and some allied genera. Am. Orchid Soc. Bull. 42: 518-524.

Chase, M.W. (1986). A reappraisal of the oncidioid orchids. Syst. Bot. 11: $477-491$.

Chase, M.W. and Hills, H.G. (1992). Orchid phylogeny, flower sexuality, and fragrance-seeking - evidence from variation in chloroplast DNA among subtribes Catasetinae and Cyrtopodiinae. BioScience 42: 4349.

Chase, M.W. and Olmstead, R.G. (1988). Isoenzyme number in subtribe Oncidiinae (Orchidaceae): an evaluation of polyploidy. Am. J. Bot. 75: 1080-1085.

Chase, M.W. and Palmer, J.D. (1992). Floral morphology and chromosome number in subtribe Oncidiinae (Orchidaceae): evolutionary insights from a phylogenetic analysis of chloroplast DNA restriction site variation. In: Molecular Systematics of Plants (Soltis, P.S., Soltis, D.E. and Doyle, J.J., eds.). Chapman and Hall, New York, pp. 324-332.

Chase, M.W. and Pippen, J. (1988). Seed morphology in the Oncidiinae and related subtribes (Orchidaceae). Syst. Bot. 13:313-323.

Christopher, J.S. and Cribb, P.J. (1984). A reassessment of the sectional limits in the genus Cymbidium Swartz. In: Orchids Biology: Reviews and Perspectives, III (Arditti, J., ed.). Cornell University Press, London, pp. 283-322.

Cogniaux, A. (1906). Orchidaceae. In: Flora Brasiliensis (Martius, C.F.P., Eichler, A.G. and Urban, I., eds.). Vol. 3. Lipsiae, Weinhein.

Daker, M.G. and Jones, K. (1969). The chromosomes of orchids. V. Stanhopeinae Benth. (Gongoriinae Aukt). Kew Bull. 24: 457-459.

De Wet, J.M.J. (1986). Hybridization and polyploidy in Poaceae. In: Grass: Systematics and Evolution (Soderstron, T., Hilu, K.W., Campbell, C.S. and Barkworth, M.E., eds.). Smithsonian Institution Press, London, pp. 188-194.

Del Prete, C., Mazzola, P. and Miceli, P. (1991). Karyological differentiation and speciation in C. Mediterranean Anacamptis (Orchidaceae). Plant Syst. Evol. 174: 115-123.

Dodson, C.H. (1957a). Oncidium pusillum and its allies I. Am. Orchid Soc. Bull. 26: 170-172.

Dodson, C.H. (1957b). Chromosome number in Oncidium and allied genera. Am. Orchid Soc. Bull. 26: 323-330.

Dressler, R.L. (1981). The Orchids: Natural History and Classification. Harvard University Press, Massachusetts.

Dressler, R.L. (1993). Phylogeny and Classification of the Orchid Family. Dioscorides Press, Portland.

Ehrendorfer, F. (1970). Evolutionary pattern and strategies in seed plants. Taxon, 19: 185-195.

Ehrendorfer, F. (1980). Polyploidy and distribution. In: Polyploidy: Biological Relevance (Lewis, W.H., ed.). Plenum Press, New York, pp. 45-60.

Fedorov, A.M.A. (Ed.) (1969). Chromosome Number of Flowering Plants. Komarov Botanical Institute, Leningrad. 
Felix, L.P. and Guerra, M. (1998). Cytological studies on species of Habenaria Willd. (Orchidaceae-Orchidoideae) occurring in the Northeast of Brazil. Lindleyana 13: 224-230.

Freudenstein, J.V. and Rasmussen, F.N. (1999). What does morphology tell us about orchid relationships? - a cladistic analysis. Am. J. Bot. 86: $225-248$.

Garay, L.A. (1972). On the origin of the Orchidaceae II. J. Arnold Arb. 53: 202-215.

Goldblatt, P. (1980). Polyplody in angiosperms: monocotyledons. In: Polyploidy: Biological Relevance (Lewis, W.H., ed.). Plenum Press, New York, pp. 219-232.

Goldblatt, P. (Ed.) (1984.) Index to Plant Chromosome Numbers 19791981. Missouri Botanical Garden, St. Louis.

Goldblatt, P. (Ed.) (1985). Index to Plant Chromosome Numbers 19821983. Missouri Botanical Garden, St. Louis.

Goldblatt, P. (Ed.) (1988). Index to Plant Chromosome Numbers 19841985. Missouri Botanical Garden, St. Louis.

Goldblatt, P. and Johnson, D.E. (Eds.) (1990). Index to Plant Chromosome Numbers 1986-1987. Missouri Botanical Garden, St. Louis.

Goldblatt, P. and Johnson, D.E. (Eds.) (1991). Index to Plant Chromosome Numbers 1988-1989. Missouri Botanical Garden, St. Louis.

Goldblatt, P. and Johnson, D.E. (Eds.) (1994). Index to Plant Chromosome Numbers 1990-1991. Missouri Botanical Garden, St. Louis.

Goldblatt, P. and Johnson, D.E. (Eds.) (1996). Index to Plant Chromosome Numbers 1992-1993. Missouri Botanical Garden, St. Louis.

Guerra, M. (1983). O uso do Giemsa na citogenética vegetal - comparação entre a coloração simples e o bandeamento. Cienc. Cult. 35: 190-193.

Guerra, M. (1987). Cytogenetics of Rutaceae IV. Structure and systematic significance of interphase nuclei. Cytologia 53: 213-222.

Guerra, M. (1999). Haematoxylin: a simple multiple-use dye for chromosome analysis. Genet. Mol. Biol. 22: 77-80.

Guerra, M. (2000). Chromosome number variation and evolution in monocots. In: Monocots II: Systematics and Evolution (Wilson, K.L. and Morrison, D.A., eds.). CSIRO Publ., Melbourne, pp. 127-136.

Harlan, J.R. and De Wet, J.M.R. (1975). On Ö Winge and a prayer: the origins of polyploidy. Bot. Rev. 41: 361-390.

Haufler, C.H. (1987). Electrophoresis is modifying our concepts of evolution in homosporous pteridophytes. Am. J. Bot. 74: 953-966.

Hoehne, F.C. (1942). Orchidaceae. In: Flora Brasilica (Hoehne, F.C., ed.) Vol. 5, Fascile 12. Secretaria da Agricultura, São Paulo.

Hoehne, F.C. (1953). Orchidaceae. In: Flora Brasilica (Hoehne, F.C., ed.) Vol. 8, Fascile 12. Secretaria da Agricultura, São Paulo.

Hunziker, J.H. and Stebbins, G.L. (1986). Chromosomal evolution in the Gramineae. In: Grass: Systematics and Evolution (Soderstron, T., Hilu, K.W., Campbell, C.S. and Barkworth, M.E., eds.). Smithsonian Institution Press, London, pp. 179-187.

Jones, K. (1974). Cytology and the study of orchids. In: The Orchids: Scientific Studies (Withner, C.L., ed.). John Willey \& Sons, New York, pp. 383-389.

Jones, K. and Daker, M.G. (1968). The chromosome of orchids: III Catasetinae Schltr. Kew Bull. 22: 421-427.

Leitch, I.J. and Bennett, M.D. (1997). Polyploidy in angiosperms. Trends Plant Sci. 2: 470-476.

Luceño, M. (1994). Cytotaxonomic studies in Iberian, Balearic, North African, and Macaronesian species of Carex Cyperaceae. II. Can. J. Bot. 72: 587-596.

Moore, R.J. (Ed.) (1973). Index to plant chromosome number 1967-1971. Regnum Veg. 90: 1-539.

Moore, R.J. (Ed.) (1974). Index to plant chromosome number 1972. Regnum Veg. 91: 1-108.
Moore, R.J. (Ed.) (1977). Index to plant chromosome number 1973-1974. Regnum Veg. 96: 1-157.

Morawetz, W. (1986). Remarks on karyological differentiation patterns in tropical wood plants. Plant Syst. Evol. 152: 49-100.

Mori, S.A., Silva, L.A.M., Lisboa, G. and Coradin, L. (1989). Manual de Manejo do Herbário Fanerogâmico. 2nd edn. CEPLAC, Ilhéus.

Okada, H. (1988). Karyomorphological observations of Apostasia nuda and Neuwiedia veratifolia (Apostasioideae-Orchidaceae). J. Jpn. Bot. 3: 344-350

Pabst, G.F.J. and Dungs, F. (1975). Orchidaceae Brasiliensis. Vol. 1. BruckeVerlag Kurt Schmersow, Hildeshein.

Pabst, G.F.J. and Dungs, F. (1977). Orchidaceae Brasiliensis. Vol. 2. BruckeVerlag Kurt Schmersow, Hildeshein.

Poggio, L., Naranjo, C.A. and Jones, K. (1986). The chromosomes of orchids IX. Eulophia. Kew Bull. 41: 45-49

Raven, P.H. (1975). The bases of angiosperm phylogeny: Cytology. Ann. MO Bot. Gard. 62: 724-764.

Röser, M. (1994). Pathways of karyological differentiation in palms (Arecaceae). Plant Syst. Evol. 189: 83-122.

Sinotô, Y. (1962). Chromosome numbers in Oncidium Alliance. Cytologia 27: 306-313.

Sinotô, Y. (1969). Chromosomes in Oncidium and allied genera, I. Genus Oncidium. Kromosomo 76: 2459-2473.

Snow, N. and MacDougal, J.M. (1993). New chromosome reports in Passiflora (Passifloraceae). Syst. Bot. 18: 261-273.

Soltis, D.E. and Soltis, P.S. (1995). The dinamic nature of polyploid genomes. Proc. Natl. Acad. Sci. USA 92: 8089-8091.

Soltis, P.S., Doyle, J.J. and Soltis, P.E. (1992). Molecular data and polyploid evolution in plants. In: Molecular Systematics of Plants (Soltis, P.S., Soltis, D.E. and Doyle, J.J., eds.). Chapman and Hall, New York, pp. 177-201.

Stace, H. M. (1995). Primitive and advanced character states for chromosome number in Gondwanan angiosperm families of Australia, especially Rutaceae and Proteaceae. In: Kew Chromosome Conference IV (Brandham, P.E. and Bennett, M.D., eds.). Royal Botanical Gardens, Kew, pp. 223-232.

Stebbins, G.L. (1966). Chromosomal variation and evolution. Science 152: 1462-1469.

Stebbins, G.L. (1971). Chromosomal Evolution in Higher Plants. Edward Arnold, London.

Stergianou, K.K. (1989). Habitat differentiation and chromosome evolution in Pleione (Orchidaceae). Plant Syst. Evol. 166: 253-264.

Tanaka, R. (1971). Types of nuclei in Orchidaceae. Bot. Mag. Tokyo 84: 118-122.

Tanaka, R. and Kamemoto, H. (1984). Chromosomes in orchids: counting and numbers. In: Orchid Biology: Reviews and Perspectives III (Arditti, J., ed.). Cornell University Press, Ithaca, pp. 324-410.

Toscano de Brito, A.L. (1998). Leaf anatomy of Ornithocephalinae (Orchidaceae) and related subtribes. Lindleyana 13: 234-283.

van der Pijl, L. and Dodson, C.H. (1966). Orchid Flowers: Their Pollination and Evolution. University of Miami Press, Coral Gabble.

Watanabe, K., King, R.M., Yahara, T., Ito, M., Yokoyoama, J., Suzuki, T. and Crawford, D.J. (1995). Chromosomal cytology and evolution in Eupatorieae (Asteraceae). Ann. MO Bot. Gard. 82: 581-592.

Williams, C.A., Toscano de Brito, A.L., Harborne, J.B., Eagles, J. and Waterman, P.G. (1994). Methylated C-glycosylflavones as taxonomic markers in orchids of the subtribe Ornithocephalinae. Phytochemistry 37: 1045-1053

Yokota, M. (1990). Karyomorphological studies on Habenaria, Orchidaceae and allied genera from Japan. J. Sci. Hiroshima Univ. 23: 53-161. 